\title{
Present state of global wetland extent and wetland methane modelling: methodology of a model inter-comparison project (WETCHIMP)
}

\author{
R. Wania ${ }^{1,{ }^{*}}$, J. R. Melton ${ }^{2, * *}$, E. L. Hodson ${ }^{3, * * *}$, B. Poulter ${ }^{4}$, B. Ringeval ${ }^{4,5,6}$, R. Spahni ${ }^{7}$, T. Bohn ${ }^{8}$, C. A. Avis ${ }^{9, * * * *}$,

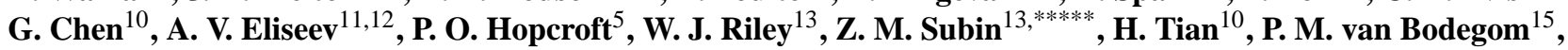 \\ T. Kleinen ${ }^{14}$, Z. C. Yu ${ }^{16}$, J. S. Singarayer ${ }^{5}$, S. Zürcher ${ }^{7}$, D. P. Lettenmaier ${ }^{8}$, D. J. Beerling ${ }^{17}$, S. N. Denisov ${ }^{11}$, \\ C. Prigent ${ }^{18}$, F. Papa ${ }^{19}$, and J. O. Kaplan ${ }^{2}$ \\ ${ }^{1}$ Institut des Sciences de l'Evolution, UMR5554, CNRS - Université Montpellier 2, Place Eugène Bataillon, \\ 34090 Montpellier, France \\ ${ }^{2}$ ARVE Group, École Polytechnique Fédérale de Lausanne, Switzerland \\ ${ }^{3}$ Swiss Federal Research Institute WSL, Switzerland \\ ${ }^{4}$ Laboratoire des Sciences du Climat et de L'Environment, CNRS-CEA, UVSQ, Gif-sur Yvette, France \\ ${ }^{5}$ BRIDGE, School of Geographical Sciences, University of Bristol, UK \\ ${ }^{6}$ Department of Earth Sciences, VU University, Amsterdam, the Netherlands \\ ${ }^{7}$ Climate and Environmental Physics, Physics Institute \& Oeschger Centre for Climate Change Research, \\ University of Bern, Switzerland \\ ${ }^{8}$ Dept. of Civil and Environmental Engineering, University of Washington, USA \\ ${ }^{9}$ School of Earth and Ocean Sciences, University of Victoria, Canada \\ ${ }^{10}$ International Center for Climate and Global Change Research and School of Forestry and Wildlife Sciences, \\ Auburn University, Auburn, AL 36849, USA \\ ${ }^{11}$ A.M. Obukhov Institute of Atmospheric Physics, Russian Academy of Sciences, Russia \\ ${ }^{12}$ Kazan (Volga region) Federal University, Russia \\ ${ }^{13}$ Earth Sciences Division (ESD), Lawrence Berkeley National Lab, USA \\ ${ }^{14}$ Max Planck Institute für Meteorologie, Hamburg, Germany \\ ${ }^{15}$ Department of Ecological Sciences, VU University, Amsterdam, the Netherlands \\ ${ }^{16}$ Department of Earth and Environmental Sciences, Lehigh University, USA \\ ${ }^{17}$ Dept. of Animal and Plant Sciences, University of Sheffield, Sheffield S10 2TN, UK \\ ${ }^{18}$ CNRS/LERMA, Observatoire de Paris, 61 Ave. de l'Observatoire, 75014 Paris, France \\ ${ }^{19}$ LEGOS, IRD, 18 Ave. Edouard Belin, 31400 Toulouse, France \\ *now at: Lanser Strasse 30, 6080 Igls, Austria \\ ** now at: Canadian Centre for Climate Modelling and Analysis, Environment Canada, Victoria, BC, V8W 2Y2, Canada \\ ${ }^{* * *}$ now at: AAAS Science and Technology Policy Fellow, Office of Climate Change Policy and Technology, \\ US Department of Energy, USA \\ **** ${ }_{\text {now }}$ at: Physics and Astronomy department, Camosun College, Victoria, BC, Canada \\ ${ }^{* * * * * *}$ now at: Princeton Environmental Institute, Princeton University, Princeton, New Jersey, USA
}

Correspondence to: J. R. Melton (joe.melton.sci@gmail.com)

Received: 30 October 2012 - Published in Geosci. Model Dev. Discuss.: 10 December 2012

Revised: 12 April 2013 - Accepted: 19 April 2013 - Published: 15 May 2013 
Abstract. The Wetland and Wetland $\mathrm{CH}_{4}$ Intercomparison of Models Project (WETCHIMP) was created to evaluate our present ability to simulate large-scale wetland characteristics and corresponding methane $\left(\mathrm{CH}_{4}\right)$ emissions. A multi-model comparison is essential to evaluate the key uncertainties in the mechanisms and parameters leading to methane emissions. Ten modelling groups joined WETCHIMP to run eight global and two regional models with a common experimental protocol using the same climate and atmospheric carbon dioxide $\left(\mathrm{CO}_{2}\right)$ forcing datasets. We reported the main conclusions from the intercomparison effort in a companion paper (Melton et al., 2013). Here we provide technical details for the six experiments, which included an equilibrium, a transient, and an optimized run plus three sensitivity experiments (temperature, precipitation, and atmospheric $\mathrm{CO}_{2}$ concentration). The diversity of approaches used by the models is summarized through a series of conceptual figures, and is used to evaluate the wide range of wetland extent and $\mathrm{CH}_{4}$ fluxes predicted by the models in the equilibrium run. We discuss relationships among the various approaches and patterns in consistencies of these model predictions. Within this group of models, there are three broad classes of methods used to estimate wetland extent: prescribed based on wetland distribution maps, prognostic relationships between hydrological states based on satellite observations, and explicit hydrological mass balances. A larger variety of approaches was used to estimate the net $\mathrm{CH}_{4}$ fluxes from wetland systems. Even though modelling of wetland extent and $\mathrm{CH}_{4}$ emissions has progressed significantly over recent decades, large uncertainties still exist when estimating $\mathrm{CH}_{4}$ emissions: there is little consensus on model structure or complexity due to knowledge gaps, different aims of the models, and the range of temporal and spatial resolutions of the models.

\section{Introduction}

In order to study the importance of wetlands in the global water and carbon cycle a variety of hydrological and biogeochemical models have been developed over the last three decades. The first studies of global-scale wetland $\mathrm{CH}_{4}$ modelling appeared twenty-five years ago (Matthews and Fung, 1987). Matthews and Fung (1987) combined vegetation, soil and fractional inundation maps along with estimates of $\mathrm{CH}_{4}$ flux intensity to generate a map of global wetland distribution and an annual wetland emissions estimate of $\sim 100 \mathrm{Tg} \mathrm{CH}_{4} \mathrm{yr}^{-1}$. Aselman and Crutzen (1989) soon followed developing their own wetland distribution datasets, and assumed $\mathrm{CH}_{4}$ emission flux rates, yielding a wetland emissions estimated range of $40-160 \mathrm{Tg} \mathrm{CH}_{4} \mathrm{yr}^{-1}$. These early approaches are limited by uncertainties inherent in upscaling point measurements to large regions, and an inability to predict changes to wetland systems due to changes in climate and hydrology because of the use of static wetland extent and simple scaling-based estimates of $\mathrm{CH}_{4}$ emissions.
As an attempt to circumvent these limitations, processbased modelling of global $\mathrm{CH}_{4}$ emissions from wetland systems was first pioneered by Fung et al. (1991) followed by Christensen and Cox (1995), Christensen et al. (1996), and Cao et al. (1996). While those early global studies used the static wetland maps of Matthews and Fung (1987), they differed in their approach to simulate the $\mathrm{CH}_{4}$ emissions. Christensen and Cox (1995) was the first study to introduce a formulation for oxidation and a soil vertical discretization in a one-dimensional, single-column model. The simple approach of Christensen et al. (1996) estimates net $\mathrm{CH}_{4}$ emissions as a fraction of heterotrophic respiration calculated by an equilibrium vegetation model (BIOME2) giving a climate sensitive, but perhaps simplistic $\mathrm{CH}_{4}$ emissions estimate. A more mechanistic approach was adopted by Cao et al. (1996) whose $\mathrm{CH}_{4}$ emission model assumes substrate supply to methanogens is controlled by plant primary productivity and soil organic matter decomposition. Methane production is then modelled as a function of soil temperature, soil organic matter decomposition, water table position, and a fixed ratio of $\mathrm{CH}_{4}$ production to decomposed organic carbon. Oxidation of produced $\mathrm{CH}_{4}$ is assumed to scale with gross primary productivity (GPP) and to increase to a fixed fraction under non-inundated conditions (Cao et al., 1996).

None of these initial modelling studies performed transient simulations and the models originally accounted for hydrologic variability only in the vertical dimension, not spatially within model grid cells. Other process-based models soon followed but were not applied on a global scale, at least initially (Walter et al., 1996; Potter, 1997; Walter and Heimann, 2000). These initial papers included mechanistic modelling of such processes as diffusive, aerenchymal, and ebullition gas and oxygen transport. More recent work has devoted much effort to improving modelling of these processes (Segers and Leffelaar, 2001; van Bodegom et al., 2001a,b; Zhuang et al., 2006) and other controls on $\mathrm{CH}_{4}$ production such as pH (Zhuang et al., 2004). Oxidation in the oxic portion of the soil, water column, and rhizosphere has also been parameterized (Ridgwell et al., 1999; Segers and Leffelaar, 2001; Zhuang et al., 2006; Curry, 2007, 2009). Model simulations have also moved on from equilibrium-only simulations to transient simulations (Walter et al., 2001a,b; Shindell et al., 2004; Gedney et al., 2004; Zhuang et al., 2006). Regional- to global-scale models have now been applied for the recent past (Ringeval et al., 2010; Hodson et al., 2011; Spahni et al., 2011; Riley et al., 2011), more distant past climates (Kaplan, 2002; Valdes et al., 2005; Hopcroft et al., 2011; Singarayer et al., 2011; Beerling et al., 2011), and to project responses to future climate change (Shindell et al., 2004; Gedney et al., 2004; Bohn et al., 2007; Bohn and Lettenmaier, 2010; Ringeval, 2011). Wetland and wetland $\mathrm{CH}_{4}$ models are now becoming included in intermediate complexity (Shindell et al., 2004; Gedney et al., 2004; Avis et al., 2011) and comprehensive (Riley et al., 2011) global climate and earth system models. 
Table 1. Description of the WETCHIMP modelling protocol.

\begin{tabular}{|c|c|c|c|}
\hline Name & Experiment & Climate years & Description \\
\hline Experiment 1 -equil & Equilibrium & $1901-1931$ & Spin-up of models with 1901-1931 climate until equilibrium. \\
\hline Experiment 2-trans & Transient & 1932-2009 & $\begin{array}{l}\text { Continuing from equilibrium, models are run transiently. } \\
\text { Comparison phase is } 1993-2004 \text {. }\end{array}$ \\
\hline Experiment 3-opt & Optimized & User-defined & $\begin{array}{l}\text { Model run with user selected "optimal" configuration. } \\
\text { Comparison phase is 1993-2004. }\end{array}$ \\
\hline Experiment $4-\mathrm{CO}_{2}$ & Atmospheric $\left[\mathrm{CO}_{2}\right]$ sensitivity & $1901-1931$ & $\begin{array}{l}\text { From the model state at end of Experiment } 1 \text {-equil simulation, } \\
\text { apply a globally uniform step increase in }\left[\mathrm{CO}_{2}\right] \text { to reach SRES } \\
\text { A2 } 2100 \text { levels }(857 \mathrm{ppmv}) \text {. Run model until equilibrium }{ }^{\mathrm{a}} \text { is } \\
\text { re-established. }\end{array}$ \\
\hline Experiment 5-T & Temperature sensitivity & $1901-1931$ & $\begin{array}{l}\text { From the model state at end of equilibrium run, apply a step } \\
\text { increase in air temperature reflecting mean SRES A2 } 2100 \text { in- } \\
\text { crease (multi-model mean SAT warming for } 2090 \text { to } 2099 \\
\text { relative to } 1980 \text { to } 1999: \approx+3.4^{\circ} \text { C). Run model until } \\
\text { equilibrium }{ }^{\text {a }} \text { re-established. }\end{array}$ \\
\hline Experiment 6-P & Moisture sensitivity & $1901-1931$ & $\begin{array}{l}\text { From the model state at end of transient equilibrium run, a step } \\
\text { increase in precipitation to reflecting mean SRES A2 } 2100 \text { in- } \\
\text { crease }(30 \mathrm{yr} \text { average } 2071 \text { to } 2100 \text { relative to } 1961 \text { to } 1990 \text { : } \\
\approx+3.9 \% \text { b } \text {. Run model until equilibrium }{ }^{\mathrm{a}} \text { re-established. }\end{array}$ \\
\hline
\end{tabular}

A number of models have also integrated approaches allowing for dynamic wetland response to climate changes. Approaches to simulate wetland distribution in order to study the interaction between climate and free water bodies were developed by Coe $(1997,1998)$ and Krinner (2003). The earliest attempt at wetland modelling for the purpose of estimating wetland $\mathrm{CH}_{4}$ emissions was designed to estimate wetland emissions during the Last Glacial Maximum (LGM, $21 \mathrm{ka}$; Kaplan, 2002). The simple scheme of Kaplan (2002) used threshold values of slope and soil moisture content to define wetland areas, with the soil moisture calculated by an equilibrium vegetation model (BIOME4); an approach adopted by other models (Shindell et al., 2004; Weber et al., 2010; Avis et al., 2011). Later schemes used land cover datasets to outline peatland regions (Wania et al., 2009a, 2010; Spahni et al., 2011), and/or satellite-derived inundation datasets to prescribe wetlands either directly (Hodson et al., 2011; Ringeval et al., 2010), or indirectly (Ringeval et al., 2011; Riley et al., 2011). Other wetland distribution schemes use internally calculated water table positions or soil moisture thresholds to locate wetlands (Chen et al., 2012).

In this context, the Wetland and Wetland $\mathrm{CH}_{4}$ Intercomparison of Models Project (WETCHIMP) was designed to offer the first multi-model comparison highlighting similarities and differences between modelling approaches and results. The advantage of using a multi-model comparison is that the range of the current state-of-the-art model estimates for wetland extent and $\mathrm{CH}_{4}$ emissions can be studied in parallel. This approach allows us to study the sources of uncertainties and spatial and temporal differences in model behaviour. The results of this multi-model comparison are presented in Melton et al. (2013). In this paper, we provide the technical background for WETCHIMP, presenting details of the modelling protocol (Sect. 2), descriptions of the models as used for WETCHIMP (Sect. 3), conceptual comparisons of the models involved and results from the model default simulation to illustrate the differences between models are presented in Sect. 4. Following the definitions set out in Melton et al. (2013), we define wetlands for the purpose of large-scale modelling as grid cells, or fractions thereof, where the land surface has inundated, or saturated, conditions. Peatlands are a form of wetlands characterized by fixed extent, at least on timescales of decades, and contrasting hydrologic and nutrient regimes between dry nutrient-poor bogs and wet nutrient-rich fens (Melton et al., 2013). Inundated areas are assumed to be wetlands (unless masked out with a rice agriculture or lake dataset) with the water table above, or at the soil surface, but do not include areas that are unsaturated at the soil surface but saturated at depth.

\section{Modelling protocol}

The models participating in WETCHIMP followed a common modelling protocol outlined in Table 1 and adhered to it as closely as possible; divergences from the modelling protocol are described in the individual model description section. 
Table 2. List of experiments (described in Table 1) performed by each of the participating modelling groups. "Prognostic" indicates that a model located at least part of its wetlands based either on an inversion to GIEMS and modelled hydrological state or used GIEMS as a spatial or temporal constraint. "Prescribed" means that the model used a distribution map for wetlands and "simulated" means that the model did not input any kind of wetland observational data to locate wetlands (see Sect. 4.1).

\begin{tabular}{lccccl}
\hline Model & Areal extent & Wetlands & $\mathrm{CH}_{4}$ fluxes & Experiments performed & Contact \\
\hline CLM4Me & global & prognostic & simulated & $1,2,3,4,5,6$ & W. J. Riley \\
DLEM & global & prognostic & simulated & $1,2,3,4,5,6$ & H. Tian \\
IAP-RAS & global & prescribed & simulated & $1,2,3,, 5,6$ & A. V. Eliseev \\
LPJ-Bern & global & prognostic & simulated & $1,2,3,4,5,6$ & R. Spahni \\
LPJ-WHyMe & $35-90^{\circ} \mathrm{N}$ & prescribed & simulated & $1,2,, 4,5,6$ & R. Wania \\
LPJ-WSL & global & prescribed & simulated & $1,2,3,4,5,6$ & E. L. Hodson \\
ORCHIDEE & global & prognostic & simulated & $1,2,3,4,5,6$ & B. Ringeval \\
SDGVM & global & simulated & simulated & $1,2,, 4,5,6$ & P. O. Hopcroft \\
UVic-ESCM & global & simulated & n/a & $1,2,3,4,5,6$ & C. A. Avis \\
UW-VIC & W-Siberia & prognostic & simulated & $1,2,3,,,$, & T. Bohn \\
\hline
\end{tabular}

* LPJ-WSL uses the "prognostic" approach for Experiment 3-opt, using GIEMS as guidance for the wetland distribution.

As briefly described in Melton et al. (2013), WETCHIMP consisted of six experiments, including both a transient simulation and several equilibrium state simulations with stepchanges to climate forcing. The first experiment ("Experiment 1-equil") was an equilibrium simulation under repeating 1901-1931 climate and a carbon dioxide concentration ([CO $\left.\mathrm{CO}_{2}\right]$ ) of 303 ppmv. The second experiment ("Experiment 2-trans") was a transient historical simulation from 19012009 , using observed climate and atmospheric $\mathrm{CO}_{2}$ concentration $\left(\left[\mathrm{CO}_{2}\right]\right)$, with the final (equilibrium) state of Experiment 1-equil as its initial state. Some models require observed fractional inundation values as an input; these were provided and cover the period 1993-2004 by the Global Inundation Extent from Multi-Satellites (GIEMS) dataset (Prigent et al., 2007; Papa et al., 2010). Thus, the period 19932004 was selected from Experiment 2-trans for comparison of model results. A third experiment ("Experiment 3-opt") was run for the same time period as Experiment 2-trans, but allowed the models to run under user-defined optimal configurations (e.g. running coupled into an earth system model or using different meteorological forcing or remotely sensed inundation datasets than those common to Experiment 2-trans).

The remaining three experiments applied step-changes to each model's equilibrium state from Experiment 1-equil. The fourth experiment ("Experiment 4- $\mathrm{CO}_{2}$ ") applied an instantaneous increase in atmospheric $\left[\mathrm{CO}_{2}\right]$ to $857 \mathrm{ppmv}$ (SRES A2 year 2100 levels from IPCC, 2000) while holding the other meteorological inputs identical to Experiment 1-equil; this perturbed simulation was then run until each model had reached a new equilibrium state. Experiment 5 ("Experiment 5-T") investigated the effect of an instantaneous increase of $+3.4^{\circ} \mathrm{C}$ in surface air temperature (SAT). The magnitude of this increase was chosen from the SRES A2 year 2100 multimodel mean SAT warming for the period 2080-2099 relative to 1980-1999 (Meehl et al., 2007). The final experiment ("Experiment 6-P") examined model responses to changes in precipitation with an instantaneous increase of $+3.9 \%$ (SRES A2 2100 level; $30 \mathrm{yr}$ global average for 2071-2100 relative to 1961-1990) (Prentice et al., 2001). In all cases, the step increases were applied to all months and grid cells uniformly. While actual changes in climate are projected to vary in both space and time, these uniform changes are suitable for the purpose of sensitivity tests (Melton et al., 2013). An overview of which groups conducted which simulations is shown in Table 2.

All data are freely available for download on http://arve. epfl.ch/pub/wetchimp, please send request for a username and password to joe.melton.sci@gmail.com.

\subsection{Datasets}

\subsubsection{Climate data}

The CRU (Climate Research Unit) TS3.1 time series (Mitchell and Jones, 2005; Jones and Harris, 2008) was used for monthly climate forcing data and - dependent on the model - precipitation, $2 \mathrm{~m}$ air temperature, percentage cloud cover, number of wet days, and vapour pressure were used from this dataset. Models that required data with a higher temporal resolution used the CRUNCEP (CRU and National Centre for Environmental Prediction) data, which is the correction of the 6 hourly NCEP reanalysis by the CRU TS3.1 data (Viovy and Ciais, 2011). CRUNCEP provides incoming long- and short-wave radiation, air specific humidity (used to compute the relative humidity), pressure, total precipitation, temperature, and the zonal and meridional components of the wind. UVic-ESCM (University of Victoria - Earth System Climate Model) used surface winds and diurnal temperature range from the NCEP reanalysis directly. 


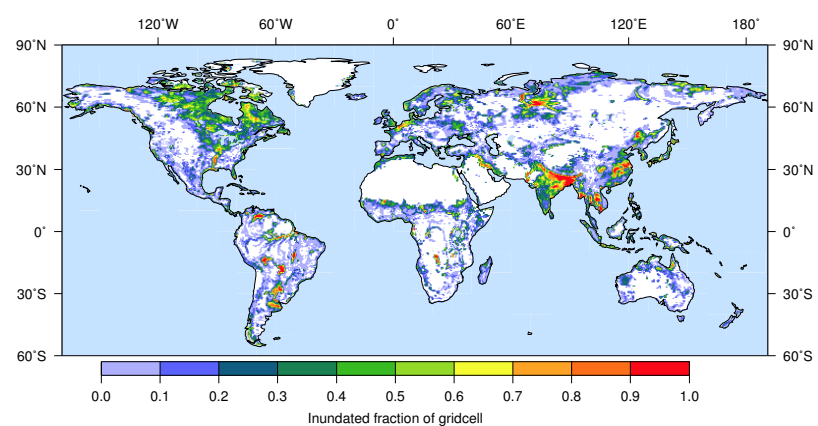

Fig. 1. Mean annual maximum fraction of inundated land between 1993 and 2004 identified by a multi-satellite approach (Papa et al., 2010). White areas indicate areas of no inundation.

\subsubsection{Soil and wetland distribution data}

The soil data used in WETCHIMP are given in Table 3 and are allocated to each model in Table 4 . The model requirements for soil data are too broad to accommodate a uniform soil dataset easily. Soil datasets used, and model treatment of soil textural information, are thus considered part of the wetland model itself.

There are several wetland distribution maps that were used for our simulations: (i) remotely sensed inundation area from GIEMS (Prigent et al., 2007; Papa et al., 2010) (Fig. 1), (ii) northern peatland distribution from NCSCD (Northern Circumpolar Soil Carbon Database; Tarnocai et al., 2007, 2009) (Fig. 2), and (iii) peatland distribution for the West Siberian Lowlands (Sheng et al., 2004) (Fig. 3). In addition, some groups made use of the rice distribution dataset by Leff et al. (2004) (Fig. 4) and the GICEW water bodies and land ice dataset (Fig. 5) to exclude areas from their wetland distribution map.

\subsubsection{Global Inundation Extent from Multi-Satellites (GIEMS)}

As the GIEMS dataset is used extensively by several models, and forms a comparison for the model outputs in Melton et al. (2013), it will be described in more detail here. The GIEMS dataset (Fig. 1) is a global, multi-year product quantifying the monthly variations of the distribution and extent of episodic and seasonal inundations, wetlands, rivers, lakes and irrigated agriculture at $0.25^{\circ}$ resolution at the equator. GIEMS is derived from a complementary suite of satellite observations including passive microwave observations (SSM/I (special sensor microwave/imager) emissivities), active microwave observations (ERS scatterometer), along with AVHRR-NDVI (Advanced Very High Resolution Radiometer-normalized difference vegetation index). The complete methodology is described in detail in Prigent et al. (2007) and Papa et al. (2010) and is briefly summarized here. First, an unsupervised classification of the three sources

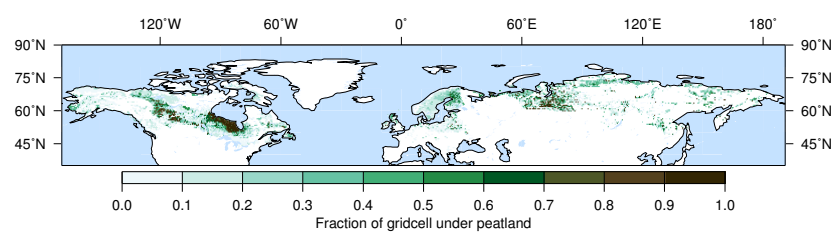

Fig. 2. Fraction of land covered by northern peatlands at present (Tarnocai et al., 2007, 2009).

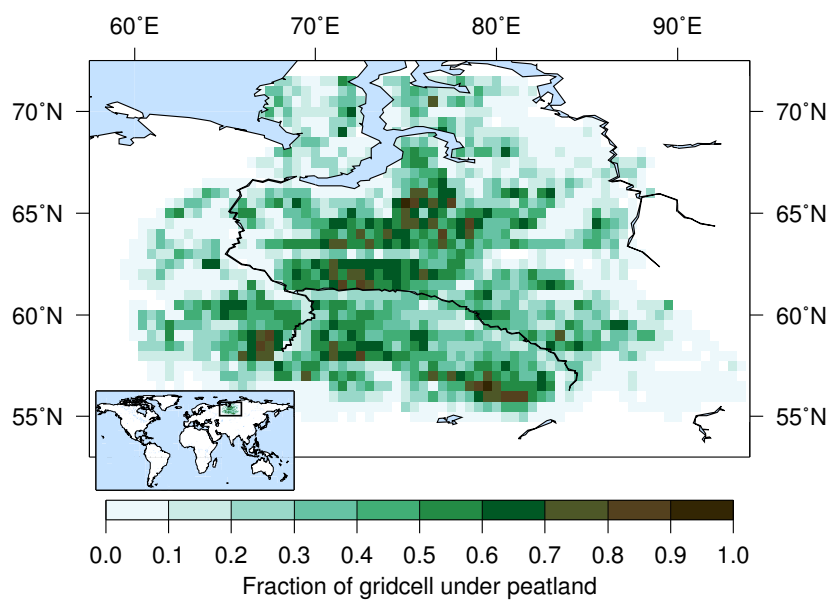

Fig. 3. Fraction of land covered by peatlands at present in the West Siberian Lowlands. Data were taken from Sheng et al. (2004) and aggregated to a $0.5^{\circ} \times 0.5^{\circ}$ grid by $\mathrm{T}$. Bohn.

of satellite data is performed, and pixels with satellite signatures likely related to inundation are retained. For each inundated pixel, the monthly fractional coverage by open water is obtained using the passive microwave signal and a linear mixture model with end-members calibrated with scatterometer observations to account for the effects of vegetation cover. We use here the dataset available at a monthly timescale for the period 1993-2004. More detailed information concerning the seasonal and inter-annual behaviour of GIEMS dataset can be found in Prigent et al. (2012) for the global-scale analysis and in Papa et al. (2006) and Papa et al. (2008) for for the tropical and boreal regions, respectively.

\section{Participating models}

In this section, we describe each model briefly and refer to published papers where more detailed information can be found. Modifications to models that were made after recent publications or specifically for WETCHIMP are described in the respective model section. An overview of which models performed which experiments is given in Table 2 and a list of forcing data for each model is provided in Table 4 . The models follow the prescribed modelling protocol listed in Table 1 unless otherwise stated in the respective model description. 
Table 3. Names and types of input datasets together with references and a list of models that used the data.

\begin{tabular}{|c|c|c|c|}
\hline Name of dataset & Description & Used by & Reference \\
\hline CRU TS3.1 & Climate & All models ${ }^{\mathrm{a}}$ & Mitchell and Jones (2005); Jones and Harris (2008) \\
\hline CRUNCEP & Climate & All models ${ }^{\mathrm{a}}$ & Viovy and Ciais (2011) \\
\hline Law Dome Composite & $\mathrm{CO}_{2}$ & All models & http://grkapweb1.epfl.ch/pub/ARVE_tech_report2_co2spline.pdf \\
\hline Dentener et al. (2006) & Nitrogen deposition & DLEM & Dentener et al. (2006) \\
\hline FAO & Soil texture classes & ORCHIDEE & Batjes (1997) \\
\hline HWSD & Soil texture classes & LPJ-Bern & FAO/IIASA/ISRIC/ISSCAS/JRC (2009) \\
\hline IGBP-DIS & Soil texture classes & CLM4Me, DLEM & Global Soil Data Task Group (2000) \\
\hline ISLSCP I & Soil texture classes & SDGVM & Sellers et al. (1996) \\
\hline ISLSCP II & $\begin{array}{l}\text { Soil texture classes, } \\
\text { soil carbon density }\end{array}$ & UVic-ESCM & ISLSCP-II (2009) \\
\hline MODIS & $\begin{array}{l}\text { Distribution of plant } \\
\text { functional types (PFTs) }\end{array}$ & UW-VIC & Bartalev et al. (2003) \\
\hline ETOPO 2v2 & Topography & SDGVM, UVic-ESCM & ETOPO (2006) \\
\hline HYDRO1k & Topography & ORCHIDEE & http://webgis.wr.usgs.gov/globalgis/metadata_qr/metadata/hydro1k.htm \\
\hline CLM soil colours & Soil colours & CLM4Me & Lawrence and Chase (2007) \\
\hline GIEMS & $\begin{array}{l}\text { Monthly inundated } \\
\text { wetland area }\end{array}$ & $\begin{array}{l}\text { CLM4Me, DLEM, } \\
\text { LPJ-Bern, LPJ-WSL, } \\
\text { ORCHIDEE, UW-VIC }^{b}\end{array}$ & Prigent et al. (2007); Papa et al. (2010) \\
\hline Schroeder et al. (2010) & $\begin{array}{l}\text { 1993-2004 (Fig. 1) } \\
\text { Remotely sensed } \\
\text { inundation dataset }\end{array}$ & UW-VIC ${ }^{c}$ & Schroeder et al. (2010) \\
\hline CDIAC NDP017 & Wetland area & IAP-RAS & http://cdiac.esd.ornl.gov/ndps/ndp017.html \\
\hline GLWD & Global land cover & DLEM & Lehner and Döll (2004) \\
\hline NCSCD & $\begin{array}{l}\text { Annual fractional } \\
\text { cover of northern } \\
\text { peatlands (Fig. 2) }\end{array}$ & $\begin{array}{l}\text { LPJ-Bern, } \\
\text { LPJ-WHyMe }\end{array}$ & Tarnocai et al. (2007, 2009) \\
\hline Sheng & $\begin{array}{l}\text { Peatland fraction (Fig. 3) } \\
\text { and peat depths }\end{array}$ & UW-VIC & Sheng et al. (2004) \\
\hline Leff & $\begin{array}{l}\text { Annual fractional cover of } \\
\text { rice fields scaled by } \\
\text { monthly inundation (Fig. } 4 \text { ) }\end{array}$ & $\begin{array}{l}\text { DLEM, } \\
\text { LPJ-Bern, } \\
\text { LPJ-WSL }\end{array}$ & Leff et al. (2004), Spahni et al. (2011) \\
\hline Fries et al. (1998) & Global land cover & DLEM & Fries et al. (1998) \\
\hline GICEW & $\begin{array}{l}\text { Waterbodies and land } \\
\text { ice excluding ice sheets (Fig. 5) }\end{array}$ & LPJ-Bern & http://luh.sr.unh.edu/ \\
\hline
\end{tabular}

${ }^{\mathrm{a}}$ These datasets were required for use in Experiments $1,2,4,5$, and $6 .{ }^{\mathrm{b}}$ Used in experiments 1 and $2 .^{\mathrm{c}}$ Used in experiment 3.

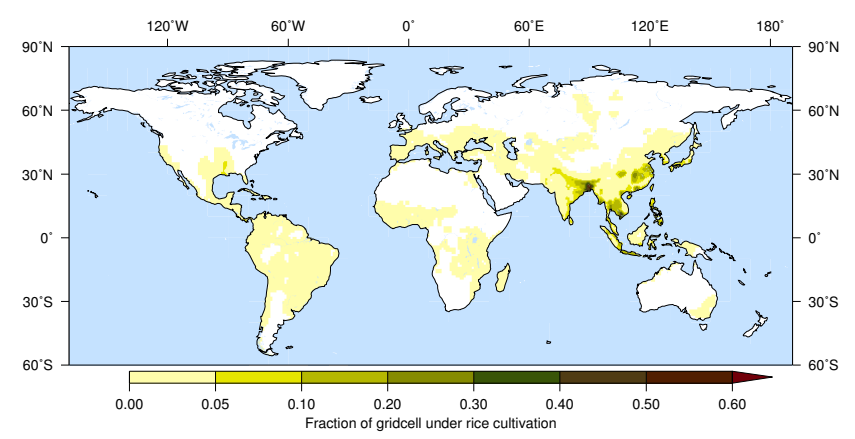

Fig. 4. Annual maximum fraction of land covered by rice fields (Leff et al., 2004).

\subsection{CLM4Me}

The version of CLM4Me used for this project is described in Riley et al. (2011), and is incorporated into the Community Land Model 4 (CLM4; Lawrence et al., 2011), the land-surface component of CESM1 (Community Earth System Model 1). Using the hydrology, soil carbon cycling, and soil thermal physics predicted in CLM4, net $\mathrm{CH}_{4}$ fluxes are computed separately in inundated and non-inundated areas in each grid cell, including uptake of atmospheric $\mathrm{CH}_{4}$. The reaction and transport equations for $\mathrm{CH}_{4}$ and oxygen (where applicable) include production, consumption, aerenchyma transport, ebullition, and diffusion.

\subsubsection{WETCHIMP set-up}

The $\mathrm{CH}_{4}$ model code deviates slightly from that described in Riley et al. (2011); these changes resulted in less than a $5 \%$ difference from the global budget presented in Riley et al. (2011). The changes in the code include: (i) the calculation of below-ground root mass for determining aerenchyma area now uses the time-lagged (1 yr decay time) belowground-toaboveground NPP (net primary productivity) ratio, instead of the instantaneous one, and (ii) in calculating the water availability for permafrost vegetation, root fraction is weighted over all soil layers down to last year's maximum active layer depth, rather than the instantaneous active layer depth, thereby causing a slight delay in growth in the spring. 
Table 4. A list of the models that contributed simulations to WETCHIMP. The "Wetland types" gives a quick overview of what kind of wetlands are used or simulated by each model. The explanations for the wetland types and soil datasets, as well as the full references are given in Table 3.

\begin{tabular}{|c|c|c|c|c|}
\hline Model & $\begin{array}{l}\text { Resolution } \\
(\text { lon } \times \text { lat })\end{array}$ & Wetland types & $\begin{array}{l}\text { Climate } \\
\text { forcing }\end{array}$ & Soil data \\
\hline CLM4Me & $2.5^{\circ} \times 1.9^{\circ}$ & $\begin{array}{l}\text { Simulated inundated area based on } \\
\text { predicted water table and runoff and } \\
\text { an inversion to GIEMS }\end{array}$ & CRUNCEP & IGBP-DIS \\
\hline DLEM & $0.5^{\circ} \times 0.5^{\circ}$ & $\begin{array}{l}\text { Mixture between prescribed and } \\
\text { simulated, rice mask by Leff }\end{array}$ & CRUNCEP & IGBP-DIS \\
\hline IAP-RAS & $0.5^{\circ} \times 0.5^{\circ}$ & $\begin{array}{l}\text { Olson data for wetlands } \\
\text { (bogs/mires, swamps, heaths/ } \\
\text { moorlands, tundra) }\end{array}$ & CRU3.1 & $\begin{array}{l}\text { Peat in peatlands, } \\
\text { loam elsewhere }\end{array}$ \\
\hline LPJ-Bern & $0.5^{\circ} \times 0.5^{\circ}$ & $\begin{array}{l}\text { Peatlands from NCSCD, inundated } \\
\text { wetlands from GIEMS, rice mask } \\
\text { by Leff, permanent water or ice } \\
\text { from GICEW, simulated wet soils }\end{array}$ & CRU3.1 & HWSD \\
\hline LPJ-WHyMe & $0.5^{\circ} \times 0.5^{\circ}$ & Peatlands from NCSCD & CRU3.1 & $\mathrm{n} / \mathrm{a}^{\mathrm{a}}$ \\
\hline LPJ-WSL & $0.5^{\circ} \times 0.5^{\circ}$ & $\begin{array}{l}\text { Inundated area from GIEMS, rice } \\
\text { mask by Leff for all experiments } \\
\text { except } 3^{\text {b }}\end{array}$ & CRU3.1 & FAO \\
\hline ORCHIDEE & $1^{\circ} \times 1^{\circ}$ & $\begin{array}{l}\text { Simulated, but annual mean over } \\
\text { 1993-2004 adjusted to mean of } \\
\text { GIEMS }\end{array}$ & CRUNCEP & FAO for mineral \\
\hline SDGVM & $0.5^{\circ} \times 0.5^{\circ}$ & All simulated & CRU3.1 & ISLSCP I \\
\hline UVic-ESCM & $3.6^{\circ} \times 1.8^{\circ}$ & All simulated & CRU3.1+NCEPC & ISLSCP II \\
\hline UW-VIC & $100 \mathrm{~km}^{\mathrm{d}}$ & Simulated lakes and peatlands & CRUNCEP & $\begin{array}{l}\text { FAO for mineral } \\
\text { soils, Sheng for } \\
\text { peatland fraction }\end{array}$ \\
\hline
\end{tabular}

\footnotetext{
a LPJ-WHyMe is a peatland only model, thus no "soil" data is required. ${ }^{\text {b }}$ LPJ-WSL Exp. 3 is a mix between prescribed (GIEMS) and simulated inundation area based upon an empirical relationship between simulated water runoff and GIEMS. ${ }^{\mathrm{c}}$ Surface winds and diurnal temperature are taken from the NCEP reanalysis. ${ }^{\mathrm{d}} 100 \mathrm{~km}$ polar azimuthal equal area grid (EASE grid), resampled to $0.5^{\circ} \times 0.5^{\circ}$.
}

The CLM model requires a number of forcings in addition to the lower atmospheric boundary conditions and fluxes specified in the CRUNCEP forcing. For all the experiments except Experiment 3-opt, the standard CLM4 year 2000 conditions are used for atmospheric $\left[\mathrm{CO}_{2}\right]$ experienced by plant stomata (except Experiment 4- $\mathrm{CO}_{2}$ ), atmospheric nitrogen deposition, atmospheric aerosol deposition, and vegetation distributions. For Experiment 3-opt, the same configuration as in Riley et al. (2011) is used, namely a spin-up to "1850" conditions using the $1850\left[\mathrm{CO}_{2}\right]$, nitrogen, aerosols, and vegetation distributions, and then repeated 1948-1972 (Qian et al., 2006) corrected-NCEP forcing. A transient simulation from 1850-2004 is run using transient data for $\left[\mathrm{CO}_{2}\right]$, nitrogen, aerosols, and vegetation, using repeated 1948-1972 forcing through 1972, at which point the model is switched to actual-year forcing through 2004.

The model is run at $1.9^{\circ} \times 2.5^{\circ}$ resolution and the standard CLM4 datasets are used, except that the default CLM4 $1 \times 10^{6} \mathrm{~km}^{2}$ of inland non-vegetated wetland area that were used in Riley et al. (2011), were eliminated. As described in that paper, the CLM4Me model requires three parameters at each grid cell to calculate the inundated fraction as a function of the modelled water table and lagged surface runoff, based on an inversion to Prigent et al. (2007) satellite observations for 1994-1998. For WETCHIMP, the parameters generated in a previous model described in Riley et al. (2011) were used (similar to Experiment 3-opt); however, the parameters were not re-optimised with the CRUNCEP forcing, hence the CRUNCEP 1990s inundated area (e.g. Experiment 2-trans) may differ from that simulated in Experiment 3-opt.

\subsection{DLEM}

The Dynamic Land Ecosystem Model (DLEM) is a processbased model that simulates daily carbon, water and nitrogen fluxes and pool sizes for land and riverine ecosystems. These pools and fluxes are influenced by changes in atmospheric chemistry $\left(\mathrm{CO}_{2}\right.$, ozone concentration and nitrogen deposition), climate, land cover and land use change, management practices (e.g. irrigation, fertilization, rotation, and technology improvement), and other disturbances (e.g. fire, hurricane, insects, disease, and forest harvest) (Tian et al., 2010, 2011a,b, 2012). For WETCHIMP, the disturbance submodel 


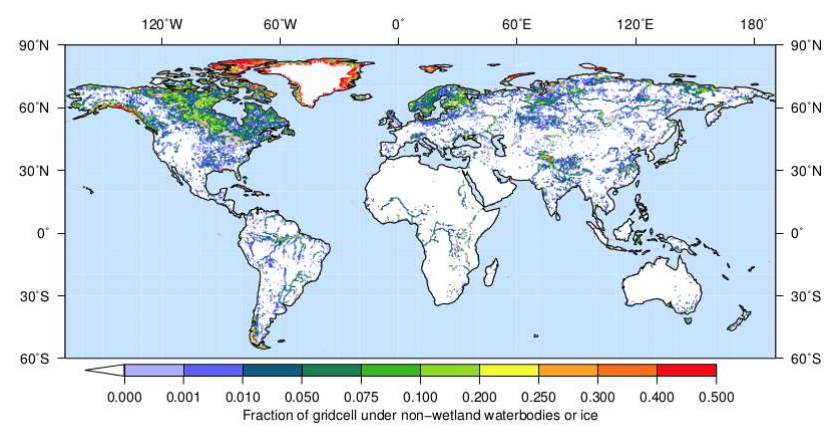

Fig. 5. Fractional grid cells covered by permanent water bodies or ice are not considered to be wetlands (GICEW, http://luh.sr.unh. $\mathrm{edu} /$ ). The Greenland ice sheet is masked out.

and the influence of ozone chemistry were not used due to a lack of spatially explicit driving data.

The soil biogeochemistry module simulates $\mathrm{CH}_{4}$ uptake in upland ecosystems and emissions in wetland ecosystems. The mechanisms and algorithms for simulating $\mathrm{CH}_{4}$ fluxes have been described in Tian et al. (2010, 2011b); Xu et al. (2010). DLEM requires input datasets for daily climate (average, maximum, and minimum air temperature, precipitation, gross radiation, and relative air humidity), atmospheric composition ( $\left[\mathrm{CO}_{2}\right]$, nitrogen deposition and ozone), annual land use information, soil condition information (soil texture, $\mathrm{pH}$, and soil depth), and topographic data (elevation, slope, and aspect).

Wetlands are defined as those areas that are inundated or saturated by surface water at a frequency and duration sufficient to support vegetation growth, which leads to five wetland types: (i) rice paddy, (ii) permanent herbaceous wetland, (iii) permanent woody wetland, (iv) seasonal herbaceous wetland and (v) seasonal woody wetland. The distribution map for different wetland types are determined based on the data from Stillwell-Soller et al. (1995); Aselman and Crutzen (1989) and Lehner and Döll (2004). DLEM simulates water transport to rivers based upon catchments, but does not explicitly move water through grid cells and thereby does not influence conditions in neighbouring grid cells. The version of DLEM used to simulate $\mathrm{CH}_{4}$ fluxes for WETCHIMP has been described by Tian et al. (2010, 2011a); Xu et al. (2010). The $\mathrm{CH}_{4}$ exchanges between ecosystems and the atmosphere are a combination of $\mathrm{CH}_{4}$ production, oxidation, and transport from soil/water to the atmosphere. DLEM only considers $\mathrm{CH}_{4}$ production from dissolved organic carbon (DOC), which is indirectly controlled by environmental factors including soil $\mathrm{pH}$, temperature, soil texture and soil moisture content.

\subsubsection{WETCHIMP set-up}

The input data except those specifically mentioned in the experimental designs were kept constant at 1993 levels during

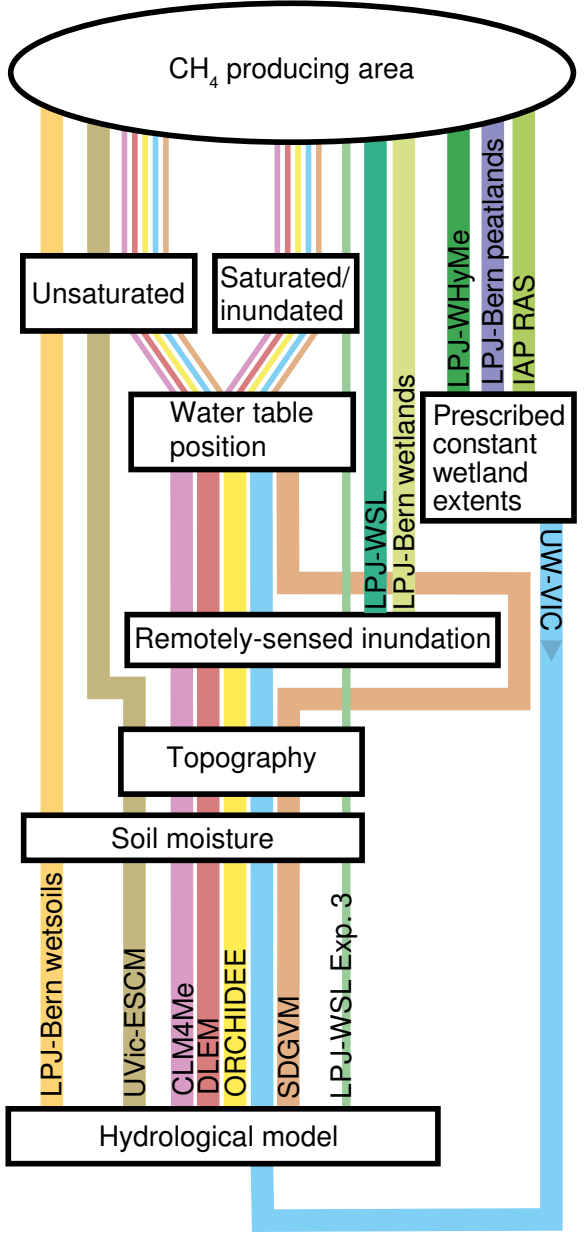

Fig. 6. Conceptual overview of how the participating models derive their " $\mathrm{CH}_{4}$ producing area" (MPA). Each model (and in some cases, version) is represented by a different colour. The flow of a particular model starts with the model's name and ends at the " $\mathrm{CH}_{4}$ producing area". The simplest models rely on "Prescribed constant wetland extents" to define their MPAs (LPJ-WHyMe, LPJBern peatlands, IAP-RAS), whereas UW-VIC uses "Prescribed constant wetland extents" only as maximal boundaries. LPJ-WSL and LPJ-Bern wetlands use remotely sensed inundation directly. "Soil moisture" is exclusively simulated by a "Hydrological model" and is used to either derive "Unsaturated" MPAs directly (LPJ-Bern wetsoils) or in combination with "Topography" (UVic-ESCM). Of the remaining models that use "Topography", all but SDGVM depend on "Remotely-sensed inundation" data to arrive at the "Water table position", which CLM4Me, DLEM, ORCHIDEE, UWVIC and SDGVM use in combination with the other factors (e.g. CLM4Me also uses runoff) to determine "Unsaturated" and "Saturated/inundated" MPAs. LPJ-WSL (Exp. 3) uses "Water table position" to obtain only the "Saturated/inundated" MPA. The order in which processes are calculated do not always strictly follow the path used in this schematic representation. 
the WETCHIMP simulations. DLEM was run at a daily time step and a $0.5^{\circ} \times 0.5^{\circ}$ spatial resolution. For experiments 1 , 4, 5, and 6, DLEM used wetland extent data in 1993 as input, while for experiments 2 and 3, transient wetland extent data was used. Before running it at the global scale, DLEM was first calibrated against field experimental and observational data. The parameters and their values were described in Tian et al. (2010) and Xu et al. (2010). The water cycle module in DLEM used for the WETCHIMP simulations differs from the previous version used in DLEM publications (e.g. Tian et al., 2012). The main difference can be found in the water cycle module, which simulates the dynamics of inundated surface water extent and water table position Liu et al., 2012. The new water cycle module uses components of previously published models, TOPMODEL (Topography based hydrological model; Beven and Kirkby, 1979), SIMTOP (Simple TOPMODEL; Niu et al., 2005) and CLM (Oleson et al., 2008), to improve its soil and surface water dynamics (Liu et al., 2012).

To integrate the GIEMS inundation fraction and rice paddy (Leff et al., 2004) datasets with the DLEM-simulated wetland distribution, some of the DLEM parameterizations were adapted for a semi-prognostic approach to determine wetland area. DLEM separately simulated the extent of two major natural wetland types: permanent and seasonal wetlands. For the permanent natural wetland distribution, areas of the GIEMS dataset that were continually inundated during the growing season (May to August) of 1993-2004 were regarded as permanent wetlands. In these areas, the soil moisture was prescribed at saturation. Excluding areas of permanent wetlands, seasonal wetlands were determined using the DLEM prognostic parameterizations as discussed previously. Thus minimum annual wetland area is controlled by the GIEMS dataset, but daily and seasonal wetland area dynamics above this were determined by internal DLEM model dynamics and controlled by the maximum wetland extent data. The maximum (or potential) wetland extent data was generated based on GIEMS data by taking the largest inundated percentage in each grid cell during 1993-2004. DLEM did not specifically separate peatland from other wetland types. Instead, we separated the five wetland types (listed above) based on the soil moisture condition and land cover types - for which the $\mathrm{CH}_{4}$ module is run. The remaining noninundated fraction in each grid cell was treated as upland land cover. We separately ran each fraction of the grid cells. Before simulations lakes and rivers were masked out using the GWLD (Global Wetland and Lakes Database) dataset (Lehner and Döll, 2004) and rice with the Leff datset (Leff et al., 2004).

\subsection{IAP-RAS model}

The present version of the IAP-RAS (Institute of Applied Physics - Russian Academy of Sciences) wetland $\mathrm{CH}_{4}$ emission module is described by Mokhov et al. (2007).
The module consists of two parts; one for soil temperature calculations, and a second for calculations of $\mathrm{CH}_{4}$ emissions. Soil temperature is calculated based on the model by Kudryavtsev et al. (1977). This model represents a generalized solution of Stephan's problem with annual temperature variations at the lower boundary of the atmosphere, while accounting for the influence of snow and moss cover. Moss cover is prescribed as a layer of $10 \mathrm{~cm}$ thickness in presence of boreal and tundra vegetation. The depth of seasonal thaw/freeze depends on the annual variation of the near-surface temperature and precipitation. The influence of the effect of snow metamorphism is ignored. The seasonal thaw depth was assessed based on the thickness of the active layer and temperature of the soil surface. Only soil layers to a certain limit depth were included in the calculations. In the standard version, the depths of 15 and $60 \mathrm{~cm}$ were used for tropical and extratropical zones, respectively. Similar depth values are obtained for the organic carbon content in soil at the characteristic peat density of $200 \mathrm{~kg} \mathrm{~m}^{-3}$ based on data from http://soils.usda.gov/use/worldsoils/mapindex/ soc.html. Deeper layers were ignored in calculations of $\mathrm{CH}_{4}$ emissions by wetlands. The amount of water in wetlands is considered to be always sufficient for inundation. Methane emissions are calculated based on the empirical model of Christensen and Cox (1995).

\subsubsection{WETCHIMP set-up}

For WETCHIMP simulations, the model was run at $0.5^{\circ} \times$ $0.5^{\circ}$ resolution using CRU TS3.1 dataset as climate forcing (Mitchell and Jones, 2005). Wetland areal extent was prescribed according to the CDIAC (Carbon Dioxide Information Analysis Center) NDP017 dataset, also known as the Olson database (http://cdiac.esd.ornl.gov/ndps/ndp017.html). In this dataset, only areas with ecosystem codes 44 ("bog/mire of cool or cold climates"), 45+72 ("warm and hot wetlands"), 64 ("heath and moorland"), and 53 ("tundra") are considered as wetlands. The inclusion of tundra regions as methane-producing area was specifically for WETCHIMP; earlier applications of IAP-RAS model neglected their contribution. Outside of wetlands, soil thermophysical parameters are homogeneously prescribed as loam everywhere.

\subsection{LPJ-Bern}

LPJ-Bern is a subsequent development of the Lund-PotsdamJena dynamic global vegetation model (Sitch et al., 2003; Joos et al., 2004; Gerber et al., 2003) that combines processbased, large-scale representations of terrestrial vegetation dynamics, soil hydrology (Gerten et al., 2004; Wania et al., 2009a), human induced land use changes (Strassmann et al., 2008; Stocker et al., 2011), permafrost and peatland establishment (Wania et al., 2009a,b) and simulation of biogeochemical trace gas emissions, such as $\mathrm{CH}_{4}$ (Wania et al., 2010; Spahni et al., 2011; Zürcher et al., 2013). 


\subsubsection{WETCHIMP set-up}

The $\mathrm{CH}_{4}$ model within the LPJ-Bern version differs slightly from the LPJ-WHyMe (LPJ Wetland Hydrology and Methane) $\mathrm{CH}_{4}$ model that was used in Wania et al. (2010) and Spahni et al. (2011). The main differences with respect to $\mathrm{CH}_{4}$ emissions concern peatland modelling, global carbon cycle parameters and input data. The differences between the model as used in this study and Spahni et al. (2011) (and thus to LPJ-WHyMe version 1.3.1, Wania et al., 2010) are described below ordered by $\mathrm{CH}_{4}$ source and sink category.

LPJ-Bern uses a different ebullition mechanism for $\mathrm{CH}_{4}$ emissions from peatlands, which includes variations in partial pressure of $\mathrm{CO}_{2}$ (Zürcher et al., 2013). The carbon balance over all layers is now preserved after every gas diffusion time step, whereas in LPJ-WHyMe a correction factor for carbon balance is applied at the end of the year. The possible plant functional types in peatlands are limited to floodtolerant graminoids and Sphagnum mosses. Additionally, the prescribed fractional peatland cover per grid cell is taken from NCSCD (Tarnocai et al., 2007, 2009). NCSCD covers histels and histosols in the northern high-latitudes with a total area of $2.7 \times 10^{6} \mathrm{~km}^{2}$, which is larger than the extent $\left(2.06 \times 10^{6} \mathrm{~km}^{2}\right)$ used in Spahni et al. (2011). The global scaling factor used by Wania et al. (2010) to account for the lack of microtopography in the model is thus reduced from 75 to $26 \%$ to constrain $\mathrm{CH}_{4}$ emissions from peatlands in 2004 to $28.2 \mathrm{Tg} \mathrm{CH}_{4} \mathrm{yr}^{-1}$ (Spahni et al., 2011).

For $\mathrm{CH}_{4}$ emissions in inundated areas the GIEMS monthly fractional inundation dataset for 1993-2004 was averaged by month (e.g. mean January, mean February, etc.). The fractional area of inundation per grid cell is further limited by the fraction of land available, i.e. land not covered by permanent water or ice (GICEW, http://luh.sr.unh.edu/). In grid cells containing peatlands $\left(35-90^{\circ} \mathrm{N}\right)$, the inundated fraction was assumed to include peatlands. If the inundated fraction exceeds the constant peatland fraction, the difference is interpreted as the inundated fraction of mineral soils. This is different to the treatment in Spahni et al. (2011), where the inundated fraction was explicitly set to zero north of $45^{\circ} \mathrm{N}$. The fraction of inundated areas was further divided into natural wetlands and rice agriculture using the scheme as described in Spahni et al. (2011). For these two categories the $\mathrm{CH}_{4}$ to $\mathrm{CO}_{2}$ conversion tuning parameter was adjusted to obtain total $\mathrm{CH}_{4}$ emissions in 2004 of $81.3 \mathrm{Tg} \mathrm{CH}_{4} \mathrm{yr}^{-1}$ for natural wetlands and of $43.1 \mathrm{Tg} \mathrm{CH}_{4} \mathrm{yr}^{-1}$ for rice agriculture (Spahni et al., 2011).

For $\mathrm{CH}_{4}$ emissions in wet mineral soils, the above changes were included and the remaining non-inundated and nonpeatland land cover was taken as fractional area of mineral soils. These mineral soils can either function as a $\mathrm{CH}_{4}$ source or sink, depending on their soil moisture (Spahni et al., 2011). For this study the $\mathrm{CH}_{4}$ to $\mathrm{CO}_{2}$ conversion factor a global scaling factor - for $\mathrm{CH}_{4}$ emissions from wet mineral soils was scaled to obtain emissions of $63.1 \mathrm{Tg} \mathrm{CH}_{4} \mathrm{yr}^{-1}$ for 2004. For the $\mathrm{CH}_{4}$ uptake the concentration-to-flux tuning factor was reduced to reach a global consumption of 25.8 $\mathrm{Tg} \mathrm{CH}_{4} \mathrm{yr}^{-1}$ (Spahni et al., 2011).

While the peatland fraction is a separate tile in each grid cell with its own carbon and soil water pools, the other three $\mathrm{CH}_{4}$ source types and the sink share the same tile. So, for the non-peatland areas, there is no interaction between water table position and vegetation growth. Compared to Spahni et al. (2011), an updated soil type map based on the World Harmonized Soil Database (FAO/IIASA/ISRIC/ISSCAS/JRC, 2009) was used by selecting the dominant soil type in each $0.5^{\circ} \times 0.5^{\circ}$ grid cell. However, soil properties for the corresponding 9 soil types were not changed to previous simulations (Spahni et al., 2011).

When model results were compared to other WETCHIMP models a unique feature was observed in $\mathrm{CH}_{4}$ emissions from northern peatlands as simulated by LPJ-Bern. Emissions for the years 1998, 1999 and 2001 are extremely high for some sites compared to average peatland emissions (Melton et al., 2013). Investigating the model output showed the high emission peaks in those years originates from $\mathrm{CH}_{4}$ gas reservoirs within and below frozen peat layers. Two processes are responsible for the establishment of these $\mathrm{CH}_{4}$ gas reservoirs. First, in LPJ-Bern, frozen peat layers act as a barrier for gas diffusion thus allowing $\mathrm{CH}_{4}$ to accumulate beneath. Second, if environmental conditions are suitable methanogenesis can occur in unfrozen layers, regardless whether layers above are frozen. Normally, $\mathrm{CH}_{4}$ production in deeper layers is negligible, but for the WETCHIMP simulations a considerable amount of $\mathrm{CH}_{4}$ gas accumulated beneath a frozen layer during the model spin-up procedure ( $1000 \mathrm{yr}$ ). This stored $\mathrm{CH}_{4}$ could not escape to the atmosphere until the year 1998 in the transient run, the first year showing an exceptional boreal warming that led to thawing of peat layers and burst emissions of $\mathrm{CH}_{4}$. While the process as such could be questioned, the magnitude of $\mathrm{CH}_{4}$ emissions is certainly too large, as can be concluded from the model-data comparison in the Hudson Bay lowlands (Melton et al., 2013).

\subsection{LPJ-WHyMe}

Methane emissions for peatlands north of $35^{\circ} \mathrm{N}$ were simulated using LPJ-WHyMe (Wania et al., 2009a,b, 2010; Spahni et al., 2011). Location and fractional cover of peatlands are taken from NCSCD (Tarnocai et al., 2007, 2009). Monthly air temperature, precipitation, percentage cloud cover and number of wet days are taken from CRU TS3.1 to force all simulations. The data from 1901-1930 are used repeatedly to spin-up the model for $1000 \mathrm{yr}$ before running it transiently, either for 1901-1930 or 1901-2009.

\subsubsection{WETCHIMP set-up}

Instead of running LPJ-WHyMe only once for an average topographical microform, two parallel runs were executed for 
each experiment. One run represents the wetter microform, lawns, which emit more $\mathrm{CH}_{4}$, and the other one represents the drier microform, hummocks. The model modifications to approximate these two microforms include setting the daily drainage rate to $0.2 \mathrm{~mm}$ (lawns) and to $0.6 \mathrm{~mm}$ (hummocks), whereas it was $0 \mathrm{~mm}$ in Wania et al. (2010). These modifications lower the water table position in hummocks compared to lawns. The vegetation for hummocks is restricted to Sphagnum mosses, whereas lawns are able to grow any plant functional type depending on the water table position (Wania et al., 2009b). Methane emissions from the two parallel runs are averaged under the assumption that hummocks and hollows cover approximately the same surface area.

\subsection{LPJ-WSL}

The LPJ-WSL $\mathrm{CH}_{4}$ model used in this analysis is the same as presented in Hodson et al. (2011), but has been recalibrated to a new set of regional $\mathrm{CH}_{4}$ fluxes as noted below. The wetland $\mathrm{CH}_{4}$ flux $(E)$ at each $0.5^{\circ} \times 0.5^{\circ}$ grid cell $(x)$ and monthly time step $(t)$ is calculated as a linear function of two scaling factors $\left(r_{\mathrm{CH}_{4}}\right.$ : $\mathrm{C}$ and $\left.f_{\text {ecosys }}\right)$, wetland extent $(A)$ and heterotrophic respiration $\left(R_{\text {hetr }}\right)$ according to the following equation:

$E(x, t)=r_{\mathrm{CH} 4: \mathrm{C}} \cdot f_{\mathrm{ecosys}}(x) \cdot A(x, t) \cdot R_{\mathrm{h}}(x, t)$.

The notation in Eq. (1) has been modified from Hodson et al. (2011) to follow Table 5 (to convert between the notation in Eq. (1) and Hodson et al. (2011): $r_{\mathrm{CH} 4: \mathrm{C}}=\beta$; $f_{\text {ecosys }}=F ; A=S$ ).

Together, $r_{\mathrm{CH} 4: \mathrm{C}}$ and $f_{\text {ecosys }}(x)$ comprise the scaling ratio $F(x)$, which converts $\mathrm{C}$ to $\mathrm{CH}_{4}$ fluxes and is a function of two weighted-regional scaling factors, one representing tropical (T) and another representing boreal (B) wetland climates (with temperate conditions represented as a combination of tropical and boreal). This approach allows the model to account for broad ecosystem differences in $\mathrm{CH}_{4}$-emitting capacity between wetland types (Eq. 2). The weighting of wetland type (i.e. tropical vs boreal) in each grid cell is calculated based on surface temperature (Eq. 3).

$$
\begin{aligned}
& F(x)=r_{\mathrm{CH} 4: \mathrm{C}} \cdot f_{\mathrm{ecosys}}(x)=\sigma(x) F_{\mathrm{T}}+(1-\sigma(x)) F_{\mathrm{B}} \\
& \sigma(x)=\exp \left(\left(T(x)-T_{\max }\right) / 8\right),
\end{aligned}
$$

where $T(x)$ is the mean near-surface temperature between 1960 and 1990 , and $T_{\max }=303.35^{\circ} \mathrm{K} . \sigma(x)$ cannot exceed 1. Equations 2 and 3 correct unintentional omissions in both equations as written in Hodson et al. (2011).

\subsubsection{WETCHIMP set-up}

For WETCHIMP, we constrained the scaling ratios, $F_{\mathrm{T}}$ and $F_{\mathrm{B}}$, by minimizing the error between our model fit, inverse modelling results (Spahni et al., 2011) and a regional flux estimate from the Hudson Bay Lowlands (PickettHeaps et al., 2011), yielding $F_{\mathrm{T}}=0.152$ and $F_{\mathrm{B}}=0.049$.
Total global wetland and rice fluxes were constrained at $215.8 \mathrm{Tg} \mathrm{CH}_{4} \mathrm{yr}^{-1}$, wetland and rice fluxes north of $45^{\circ} \mathrm{N}$ at $39.6 \mathrm{Tg} \mathrm{CH}_{4} \mathrm{yr}^{-1}$ (Spahni et al., 2011), and wetland and rice fluxes from $50-60^{\circ} \mathrm{N}$ and $75-96^{\circ} \mathrm{W}$ at $2.3 \mathrm{Tg} \mathrm{CH}_{4} \mathrm{yr}^{-1}$ (Pickett-Heaps et al., 2011). These are different constraints than were used in Hodson et al. (2011).

$R_{\text {hetr }}$ was calculated using the LPJ-WSL dynamic global vegetation model (DGVM), based on the LPJv3.1 DGVM (Sitch et al., 2003; Gerten et al., 2004). The monthly climatology inputs (precipitation, mean temperature, cloud cover, wet days) were taken from CRU TS3.1 and the non-gridded annual $\mathrm{CO}_{2}$ concentration inputs to LPJ-WSL are described in Hodson et al. (2011). In addition, as in Hodson et al. (2011), soil texture was prescribed from the Food and Agriculture Organization (Zobler, 1986), using a 2-soil layer hydrological model with a total soil depth of $1.5 \mathrm{~m}$. For scenarios 2 and 3, a $1000 \mathrm{yr}$ spin-up was implemented by recycling the first $30 \mathrm{yr}$ of climate data (1901-1930) with preindustrial $\mathrm{CO}_{2}$ concentrations to equilibrate soil and vegetation carbon pools, followed by a transient climate and $\mathrm{CO}_{2}$ simulation running from 1901-2005. For scenarios 1, 4, 5, and 6, instead of using a repeating 1901-1930 climate, first a 12 monthly mean annual dataset was created and repeated until equilibrium is reached. The default soil respiration equation in LPJ was used for all scenarios except experiment 3 .

We used the same temperature and moisture dependent equation as in Hodson et al. (2011), which allows the soil respiration to drop to zero when soil moisture is zero. For experiment 3, we used the soil moisture-respiration equation from Sitch et al. (2003) that fixes the soil respiration to a minimum of 0.25 in the upper one meter of soil, even when soil moisture drops to values below 0.25 .

For all experiments except experiment 3 , wetland extent (A) represents natural wetlands and lakes and is the original, monthly varying GIEMS inundation dataset processed to $0.5^{\circ} \times 0.5^{\circ}$ spatial resolution with rice growing regions removed (Leff et al., 2004). For experiments 1, 4, 5, and 6, this wetland area satellite product was averaged across all years from 1993-2004 to create a 12 month mean wetland area product. For experiment 3 , a combined satellite and model product was used, which is described in Hodson et al. (2011).

\subsection{ORCHIDEE}

The ORCHIDEE (Organising Carbon and Hydrology in Dynamic Ecosystems) model (Krinner et al., 2005) has been implemented with a wetland $\mathrm{CH}_{4}$ emissions scheme. This version of ORCHIDEE has been previously used to simulate the evolution of wetland $\mathrm{CH}_{4}$ emissions under future climate change (Koven et al., 2011) and to study the feedback between climate, atmospheric $\mathrm{CH}_{4}$, and $\mathrm{CO}_{2}$ (Ringeval et al., 2011). Simulations of ORCHIDEE for the current time period have also been performed and evaluated against topdown simulations to investigate the role of wetlands in the 
Table 5. A general description of the dependencies of $\mathrm{CH}_{4}$ production, $\mathrm{CH}_{4}$ oxidation (does not include atmospheric $\mathrm{CH}_{4}$ oxidation) and $\mathrm{CH}_{4}$ flux. All of the fluxes are modulated by a $\mathrm{CH}_{4}$-producing area (see Fig. 6). Parameters and variables used in the models were harmonized where possible, but identical names do not indicate identical values in the different models.

\begin{tabular}{|c|c|c|c|c|}
\hline Model & $\mathrm{CH}_{4}$ production $(P)$ & $\mathrm{CH}_{4}$ oxidation $(O)$ & Atmospheric $\mathrm{CH}_{4}$ oxidation $\left(O_{\mathrm{atm}}\right)$ & Net $\mathrm{CH}_{4}$ flux $(F)$ \\
\hline CLM4Me & $P=R_{\mathrm{het}} r_{\mathrm{CH} 4: \mathrm{C}} f_{\mathrm{pH}} f_{\mathrm{pE}} Q_{10}$ & $O=O_{\max } f_{\left[\mathrm{O}_{2}\right]} f_{\left[\mathrm{CH}_{4}\right]} f_{\Theta} Q_{10}$ & $O_{\mathrm{atm}}=R_{\mathrm{O}, \max } f_{\left[\mathrm{O}_{2}\right]} f_{\mathrm{atm}\left[\mathrm{CH}_{4}\right]} f_{\left[\mathrm{CH}_{4}\right]} f_{\Theta} Q_{10}$ & $F=(P-O) f_{\text {transport }}-O_{\text {atm }}$ \\
\hline DLEM & $P=P_{\max } \mathrm{C}_{\text {labile }} f_{T} f_{\mathrm{pH}} f_{\Theta}$ & $\begin{array}{l}O_{\text {trans }}=O_{\text {trans,max }} f_{\text {planttrans }} f_{T} \\
\left.O_{\text {soil }}=O_{\text {soil,max }} f_{[\mathrm{CH}} f_{4}\right] T_{\text {soil }} f_{\mathrm{pH}} f_{\text {oxid }, \Theta}\end{array}$ & $O_{\text {atm }}=O_{\text {atm,max }} f_{\text {atm }\left[\mathrm{CH}_{4}\right]} f_{T_{\text {air }}} f_{\mathrm{pH}} f_{\text {oxid }, \Theta}$ & $F=\left(P-O_{\text {trans }}-O_{\text {soil }}\right) f_{\text {transport }}-O_{\text {atm }}$ \\
\hline IAP-RAS & $P=f_{T}$ & - & - & $F=P f_{\Theta} Q_{10}$ \\
\hline LPJ-Bern peat & $P=R_{\text {het }} r_{\text {CH } 4: \mathrm{C}} f_{\text {root }} f_{\text {WTP }}$ & $O=f_{\left[\mathrm{O}_{2}\right]} f_{\left[\mathrm{CH}_{4}\right]^{\mathrm{O}_{2}}}$ & - & $F=(P-O) f_{\text {transport }}$ \\
\hline LPJ-Bern wetlands & $P=R_{\text {het }} r_{\mathrm{CH} 4: \mathrm{C}}$ & - & - & $F=P$ \\
\hline LPJ-Bern rice & $P=R_{\text {het }}{ }^{r} \mathrm{CH} 4: \mathrm{C}$ & - & - & $F=P$ \\
\hline LPJ-Bern wetsoils & $P=R_{\text {het }} r_{\mathrm{CH} 4: \mathrm{C}} f_{\Theta}$ & - & $O_{\mathrm{atm}}=f_{\mathrm{atm}\left[\mathrm{CH}_{4}\right]} f_{T} f_{\Theta} f_{\text {soil }}$ & $F=P-O_{\mathrm{atm}}$ \\
\hline LPJ-WHyMe & $P=R_{\text {het }} r_{\mathrm{CH} 4: \mathrm{C}} f_{\text {root }} f_{\mathrm{WTP}}$ & $O=f_{\left[\mathrm{O}_{2}\right]} f_{\left[\mathrm{CH}_{4}\right]} r_{\mathrm{O}_{2}}$ & - & $F=(P-O) f_{\text {transport }}$ \\
\hline LPJ-WSL & $P=R_{\text {het }} r_{\mathrm{CH} 4: \mathrm{C}} f_{\text {ecosys }}$ & - & - & $F=P$ \\
\hline ORCHIDEE & $P=R_{0} \mathrm{C}_{\text {labile }} f_{\mathrm{WTP}} f_{T} Q_{10}$ & $O=f_{\mathrm{WTP}} f_{\left[\mathrm{CH}_{4}\right]} Q_{10}$ & - & $F=(P-O) f_{\text {transport }}$ \\
\hline SDGVM & 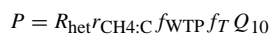 & $O=0.9 P$ & - & $F=P-O$ \\
\hline UW-VIC & $P=R_{0} f_{\mathrm{NPP}} f_{\text {root }} f_{T} Q_{10}$ & $O=f_{\left[\mathrm{CH}_{4}\right]} Q_{10}$ & - & $F=(P-O) f_{\text {transport }}$ \\
\hline
\end{tabular}

current atmospheric $\mathrm{CH}_{4}$ concentration growth rate (Pison et al., 2013).

The wetland $\mathrm{CH}_{4}$ emissions, $E_{\mathrm{CH}_{4}}(g, t)$, are computed for each grid cell, $g$, and for each time step, $t$, through the following equation:

$E_{\mathrm{CH}_{4}}(g, t)=\sum_{\mathrm{WTP}_{i}} S_{\mathrm{WTP}_{i}}(g, t) D_{\mathrm{WTP}_{i}}(g, t)$,

where $S_{\mathrm{WTP}_{i}}$ is the fraction of $g$ covered by a wetland whose water table position (WTP) is equal to $\mathrm{WTP}_{i} . D_{\mathrm{WTP}_{i}}$ is the $\mathrm{CH}_{4}$ flux (i.e. $\mathrm{g} \mathrm{CH}_{4}\left(\mathrm{~m}^{-2}\right.$ ofwetland) time ${ }^{-1}$ ) for a wetland whose water table position is equal to $\mathrm{WTP}_{i} . S_{\mathrm{WTP}_{i}}$ and $D_{\mathrm{WTP}_{i}}$ are, respectively, computed by (i) the coupling between a TOPMODEL (Beven and Kirkby, 1979) approach and ORCHIDEE, and (ii) the coupling between a (slightly modified) version of the Walter et al. (2001a) model and ORCHIDEE.

The main modification to the Walter et al. (2001a) model, as described in Ringeval et al. (2010), concerns the methanogenesis substrate. A fraction, $\alpha$, of the natural labile carbon pool computed by ORCHIDEE is used to estimate the methanogenesis substrate. The $\alpha$ parameter also encompasses the methanogenesis base rate at the reference temperature (see Ringeval et al., 2013). $\alpha$ has been optimized against three sites then extrapolated on all grid cells sharing the same vegetation type (boreal, temperate or tropical).

In contrast to LPJ-WHyMe and its derivatives, ORCHIDEE did not implement wetland-specific PFTs (plant functional types). Instead, a fraction of the mean natural labile carbon pool over the grid cell is used to estimate the substrate supply.
For the computation of $S_{\mathrm{WTP}_{i}}$ in each grid cell, TOPMODEL allows distribution of the mean water deficit computed by ORCHIDEE according to the sub-grid topographic index distribution. This leads to the diagnostic of the gridcell fraction with a null deficit. The mean deficit over the grid cell is computed from a gap to the field capacity (and not to the saturation, which cannot be reached in ORCHIDEE). The saturated wetland extent is computed from these "field capacity extents" using a shift of the topographic index distribution into each grid cell. The value of this shift is the same for all grid cells and has been chosen to obtain a global coverage by wetlands close to $4 \%$. The simulated wetland extent has been evaluated both through the induced modification on the simulated river flows and against the GIEMS data (Ringeval et al., 2012). The TOPMODEL approach is used to simulate not only the saturated wetland extent but also the wetland extent with a WTP below the soil surface.

\subsubsection{WETCHIMP set-up}

In the simulations performed for the WETCHIMP intercomparison, the $\mathrm{WTP}_{i}$ values chosen for each grid cell are: $0,-3$ and $-9 \mathrm{~cm}$. A value of water table position equal to 0 means that the water is at the soil surface while negative values corresponds to water table position below the soil surface. Thus, for each time step, three fractions of each grid cell are given: (i) a fraction covered by a saturated wetland, (ii) a fraction covered by a wetland with a mean WTP equal to $-3 \mathrm{~cm}$ (i.e. where the deficit is between 0 and $-6 \mathrm{~cm}$ ) and (iii) a fraction covered by a wetland with a mean WTP equal to $-9 \mathrm{~cm}$ (i.e. where the deficit is between -6 and $-12 \mathrm{~cm}$ ). 
As in Ringeval et al. (2011) the wetland extent is corrected to subtract the systematic biases of the model by normalizing the mean yearly wetland extent to the GIEMS data (i.e. both the seasonal and year to year variability come from TOPMODEL). In the WETCHIMP simulations, a $Q_{10}$ equal to 3 (close to the mean value in Ringeval et al., 2010) has been chosen for all grid cells. As in Ringeval et al. (2013), the reference temperature for methanogenesis is defined as the mean surface temperature computed by ORCHIDEE when forced by the 1960-1991 CRUNCEP climatology.

\subsection{SDGVM}

The SDGVM (Sheffield Dynamic Global Vegetation Model; Woodward et al., 1995; Beerling and Woodward, 2001) was used in conjunction with a modified version of the Cao et al. (1996) wetland emissions model to perform the WETCHIMP simulations. The modelling set-up follows the approach of Singarayer et al. (2011), however in that study an equilibrium approach was taken wherein the vegetation and $\mathrm{CH}_{4}$ models were forced with averaged ( $30 \mathrm{yr}$ ) climatologies from a series of general circulation model simulations. For WETCHIMP, a transient approach was required whereby the models were forced sequentially with monthly climatic inputs. The SDGVM and $\mathrm{CH}_{4}$ models were therefore run in a similar manner as described by Hopcroft et al. (2011), in which a transient set-up of the model is described.

SDGVM requires monthly mean inputs of surface air temperature, precipitation and relative humidity, as well as a map of soil texture and global annual mean atmospheric $\mathrm{CO}_{2}$ concentrations. The CRU vapour pressure was converted to relative humidity using standard formulae, whilst the temperatures and precipitation were used without modification.

In the $\mathrm{CH}_{4}$ model, the supply of carbon substrate for methanogenesis is taken to scale with $1 \mathrm{~m}$ soil heterotrophic respiration as simulated in SDGVM. $1 \mathrm{~m}$ is the model's soil depth. $\mathrm{CH}_{4}$ production, $M_{\text {prod }}$, is then given by

$M_{\text {prod }}=R_{\text {hetr }} P_{0} f_{\mathrm{w}}(\mathrm{WTP}) f_{T}(T)$,

where $R_{\text {hetr }}$ is the soil heterotrophic respiration rate $\left(\mathrm{g} \mathrm{C} \mathrm{m}^{-2}\right.$ month $^{-1}$ ) from SDGVM, $P_{0}$ represents the fraction of decomposed matter converted to $\mathrm{CH}_{4}$ under optimal conditions $\left(0.47\right.$, see Cao et al., 1996). $f_{\mathrm{w}}$ and $f_{T}$ are dimensionless scaling functions, which parameterize the effects of water table position (WTP, in $\mathrm{cm}$, positive up from the soil surface) and temperature $\left(T\right.$ in $\left.{ }^{\circ} \mathrm{C}\right)$ on emission rates. These are given by

$$
\begin{aligned}
& f_{\mathrm{W}}(\mathrm{WTP})=0.383 e^{0.096 \times \mathrm{WTP}}, \quad \mathrm{WTP} \leq 10 \mathrm{~cm} ; \\
& f_{T}(T)=\frac{e^{0.0405 \times T}}{3.375}, \quad 5^{\circ} \mathrm{C}<T \leq 30^{\circ} \mathrm{C},
\end{aligned}
$$

where $f_{\mathrm{W}}$ is 1.0 for WTP $>10 \mathrm{~cm}$ and $f_{T}$ is 1.0 for $T>$ $30^{\circ} \mathrm{C}$ and 0.0 for $T \leq 5.0^{\circ} \mathrm{C}$. Emissions thus increase with increasing water table depth (up to $10 \mathrm{~cm}$ ). $f_{\mathrm{w}}$ follows observations from Roulet et al. (1992) and Eq. (7) implies a $Q_{10}$ value of $1.5 .90 \%$ of $\mathrm{CH}_{4}$ produced is assumed to be oxidised. The water table position in each grid cell is calculated from the SDGVM simulated $1 \mathrm{~m}$ total soil moisture content using the relations from Cao et al. (1996) for tundra (their Eqs. 15, 16) and a constant global soil porosity.

SDGVM also includes the biogeochemical coupling between the above- and below-ground carbon and nitrogen cycles. This is an important feature of modelling realistic changes in land surface primary production, which depends on, and should be in line with, realistic biological and anthropogenic nitrogen fixation rates (Hungate et al., 2003). In SDGVM, litter production influences soil carbon and nitrogen pools via the Century soil nutrient cycling model (Parton et al., 1993), which in turn feedback to influence the primary production of vegetation; details are provided elsewhere (Beerling and Woodward, 2001).

\subsubsection{WETCHIMP set-up}

The model output saved from SDGVM simulations includes annual NPP, soil carbon content, monthly heterotrophic respiration, soil moisture content, and GPP. The monthly outputs of $\mathrm{CH}_{4}$ emissions and water table position were saved from the $\mathrm{CH}_{4}$ model. The experiment protocol called for monthly and annual maximum wetland area (mmax_weta, amax_weta). Wetland area in this model is not used by the emissions model, which is instead a function of water table position (see Eq. 5). $\mathrm{CH}_{4}$ emitting area could be used as a proxy for wetland area, but this would include grid cells with a water table far from the surface and with very small $\mathrm{CH}_{4}$ fluxes. Since most of the other models in the intercomparison were parameterized using inundated area from satellite observations, the SDGVM output was tailored to be somewhat comparable. The wetland area was here taken as simulated inundated area. Since there is no sub-grid hydrology in the model, in each grid cell this area will either be 0 or the area of the grid cell. However, the model includes a correction for sub-grid orography based on the ETOPO5 dataset, which is applied to $\mathrm{CH}_{4}$ emissions. The orographic correction, $F_{\text {corr }}$ is computed as:

$F_{\text {corr }}=\frac{0.01-S_{\max }}{0.01}$,

where $S_{\max }$ is the maximum gradient between a grid cell and its 8 nearest neighbours. This correction was also applied to the calculated inundation area. Two climate-dependent conditions on $\mathrm{CH}_{4}$ emissions are also currently used within the model: (i) the monthly air temperature must be above $5^{\circ} \mathrm{C}$, and (ii) if the temperature in a given grid cell during the current year is always $>0{ }^{\circ} \mathrm{C}$, then in a given month, the evapotranspiration must not exceed precipitation. These two conditions were both also used to correct the simulated inundated area, so that it is more directly relevant to the simulated $\mathrm{CH}_{4}$ emissions. 


\subsection{UVic-ESCM}

The UVic Earth System Climate Model (Weaver et al., 2001; Meissner et al., 2003) is an intermediate complexity climate model consisting of several coupled components: an energymoisture balance atmospheric model, a three-dimensional ocean general circulation model, a dynamic-thermodynamic sea ice model and a land surface scheme, which includes a representation of vegetation dynamics. The model was recently modified to include a representation of permafrost and global wetlands (Avis et al., 2011). Wetlands in the UVic model are determined using empirically derived threshold values for unfrozen soil moisture content and terrain slope so that wetlands are present where ground is sufficiently wet and flat (Kaplan, 2002). Wetlands are either "on or off" in a particular grid cell. If they satisfy the soil moisture criterion they are "on" and they occupy the fraction of the grid cell with the requisite terrain slope. Organic and mineral soil properties were specified by using the ISLSCP-II (International Land-Surface Climatology Project II) datasets as the model is presently incapable of generating the observed high soil carbon values in northern high latitudes (none of the participating models is able to couple soil biogeochemical with thermal characteristics yet).

\subsubsection{WETCHIMP set-up}

The UVic model is nominally run in a fully coupled configuration with coupling between atmospheric, ocean, land surface and other model components. For the purpose of participating in WETCHIMP, the land surface scheme was decoupled from the other model components and run in an offline configuration. This offline configuration uses the monthly CRU data to drive the land surface scheme. The model smoothly interpolates between these CRU fields to obtain data for a particular time step. Some of the atmospheric code from the coupled model's energy-moisture balance model (Weaver et al., 2001) was retained to calculate factors such as incoming solar radiation, which needs to be specified to the land surface scheme and was not specified in the monthly CRU datasets.

Surface air temperature, precipitation and relative humidity were specified from the CRU data, while surface winds and the diurnal temperature range were drawn from the NCEP reanalysis. Incoming long- and short-wave radiation are calculated within the model's atmospheric module.

The land surface scheme also has the capacity to simulate vegetation dynamics using the TRIFFID (Top-down Representation of Interactive Foliage and Flora Including Dynamics) dynamic vegetation model (Cox, 2001). As vegetation parameters were derived based on the coupled model climate, for the purposes of the WETCHIMP simulations, the vegetation distribution and characteristics were fixed and set equal to their mean year-1900 values from an equilibrated version of the coupled model, rather than adjusting vegetation parameters to fit the CRU climate data. Monthly mean fields of vegetation fraction, leaf area index (LAI), vegetation height and litterfall are then obtained from the mean year-1900 model output. The vegetation dynamics are consequently switched off for the offline run, and vegetation parameters for a given model time step are specified by smoothly interpolating between these monthly fields. Nonplant competition based vegetation parameters do remain interactive in the model. For example, plant stomata still open and close in response to factors like changing soil moisture or atmospheric $\mathrm{CO}_{2}$ concentration.

For the equilibrium run, the model was forced repeatedly with 1901-1931 data for $2000 \mathrm{yr}$. This time period was found to be sufficient to allow for equilibration of soil moisture and temperature variables. When applying the $\mathrm{CO}_{2}$, temperature and moisture runs, the 1901-1931 spin-up period was repeated for an additional $2000 \mathrm{yr}$ to allow a new equilibrium to be established.

\subsection{UW-VIC}

The University of Washington team used the Variable Infiltration Capacity (VIC) model, version 4.1.2, with some extensions specifically tailored for the modelling of boreal peatlands described in Bohn et al. (2007) and Bohn and Lettenmaier (2010). UW-VIC is a large-scale hydrologic model that balances the water and energy budgets of the land surface at an hourly time step and spatial resolutions ranging from $1^{\circ}$ to $5 \mathrm{~km}$. Most of the model physics are described in Liang et al. (1994). Land cover is represented as a collection of "tiles", each containing a different plant functional type, overlaying a single soil column divided into 3 hydrologic layers, down to varying depths, but generally no deeper than $3 \mathrm{~m}$. While UW-VIC does not track the storage of carbon in biomass, it computes NPP via a scheme taken from the BETHY (Biosphere Energy-Transfer and Hydrology) model (Knorr, 2000). The seasonal cycle of LAI is prescribed at each grid cell based on the MODIS (Moderate Resolution Imaging Spectroradiometer) LAI product (Myneni et al., 2002). Stomatal resistance is a function of day length, temperature, soil moisture, and vapor pressure deficit. UW-VIC models permafrost and the soil temperature profile via the finite difference scheme of Cherkauer and Lettenmaier (1999) with an exponential node distribution down to $50 \mathrm{~m}$ depth and a no-flux bottom boundary condition. Thermal properties of organic soil are also taken into account (Farouki, 1981). To account for dynamic surface water storage (lakes and seasonally flooded wetlands) UWVIC's lake/wetland model was employed (Bowling and Lettenmaier, 2010). This feature allocates one land cover tile to contain a combination of a lake (representing all lakes in the grid cell) and its surrounding catchment. Within the tile, the inundated area fraction is dynamic, changing as a function of storage and bathymetry. The extent of permanent lakes were assumed equal to the minimum annual observed inundation 
extent from the remotely observed inundation datasets (either Schroeder et al. (2010) or GIEMS, see Table 3). Thus, while the minimum and maximum possible extent of inundation within a grid cell are prescribed, the actual inundated extent is a dynamic function of environmental conditions. In the exposed portion of the tile, the water table position is assumed to have a distribution based on peatland microtopography: the peatland consists of a mix of hummocks (or ridges) and hollows (or pools), with the peat underneath hummocks up to $70 \mathrm{~cm}$ thicker than under the deepest points of the hollows. The fraction of peatland covered by hummocks is a calibrated parameter. Local water table position under any given point is computed as a function of soil moisture via the formulation described in Frolking et al. (2002). Methane emissions were computed for the lakes, inundated wetlands, and each point in the water table position distribution in the exposed wetlands as a function of water table position, soil temperature, and NPP via the model of Walter and Heimann (2000). A lake emission rate of $375 \mathrm{mg} \mathrm{CH}_{4} \mathrm{~m}^{-2} \mathrm{~d}^{-1}$ was originally assumed during the ice-free season and half that rate during ice-covered season. This rate was found to be in error due to an artefact in the satellite data used to parameterize the lake emission rates. A value of $0 \mathrm{mg} \mathrm{CH}_{4} \mathrm{~m}^{-2} \mathrm{~d}^{-1}$ is now used. The new lake emission rate results in lake $\mathrm{CH}_{4}$ emissions that more closely resemble observations from the area. The influence of the new value can be observed by comparing from Melton et al. (2013) Fig. A1j (375 $\left.\mathrm{mg} \mathrm{CH}_{4} \mathrm{~m}^{-2} \mathrm{~d}^{-1}\right)$ and Fig. $8 \mathrm{j}\left(0 \mathrm{mg} \mathrm{CH}_{4} \mathrm{~m}^{-2} \mathrm{~d}^{-1}\right)$.

\subsubsection{WETCHIMP set-up}

For these simulations, each grid cell was separated into two parts: an upland fraction, underlain by mineral soils, with soil textures supplied by the FAO Digital Soil Map of the World (Batjes, 1997); and a lake/wetland fraction, underlain by peat soils, with peat depths given by the database of Sheng et al. (2004) and other characteristics taken from Letts et al. (2000). Simulations were run separately for each portion of the grid cell. The lake/wetland portion of each grid cell was determined as the superset of the Sheng et al. (2004) peatland map; wetlands, wet tundra, and croplands (so that nearby lakes could have a surrounding catchment) given by the Bartalev et al. (2003) land cover classification; and lakes given by the Global Lake and Wetland Database (GLWD; Lehner and Döll, 2004). Bathymetries for the lake/wetlands were estimated by combining lake size distributions from the GLWD; average lake depths from literature for bog pools, Arctic thaw lakes, and other boreal lakes; and topography of surrounding wetlands from the ASTER (Advanced Spaceborne Thermal Emission and Reflection Radiometer) (Hayakawa et al., 2008) and STRM (Shuttle Topography Radar Mission; Digital Elevation Model ) (Farr and Kobrick, 2000) DEMs. When lake storage increased beyond the bounds of the "permanent" lake, it was allowed to flood the surrounding wetlands, with drainage rate controlled by a calibrated parameter. Both this parameter and the area fraction of hummocks within the peatland were calibrated to optimize the match with global inundation datasets. For the optimized runs (Experiment 3), the global daily AMSRE/QuickSCAT-based dataset of Schroeder et al. (2010) was used; for all other runs, the GIEMS dataset was used (Prigent et al., 2007; Papa et al., 2010). Parameters for the $\mathrm{CH}_{4}$ emissions model were calibrated to optimize the in situ observations of Glagolev et al. (2010) across West Siberia. For experiments other than experiment 3, UW-VIC's parameters were calibrated to match the June/July/August average inundation given by the GIEMS dataset over the period 19932004 and used for years outside of that range.

\section{Results and discussion}

We provide two conceptual overviews of the participating models highlighting similarities as well as differences between the chosen approaches. These overviews are designed to assist discussions of the differences in modelling results (Melton et al., 2013), but they also represent the first attempt at conceptually describing the state-of-the-art approaches used in wetland extent and wetland $\mathrm{CH}_{4}$ modelling. For the conceptual figures describing the modelling approaches, we defined two variables of interest: the $\mathrm{CH}_{4}$ producing area (Fig. 6) and $\mathrm{CH}_{4}$ flux (Fig. 7). We used these metrics to explore the dominant processes responsible for differences between the models.

\section{1 $\mathrm{CH}_{4}$ producing area}

We use the term " $\mathrm{CH}_{4}$ producing areas" (MPAs) to include all terrestrial areas that may produce $\mathrm{CH}_{4}$ biogenically. We include wet mineral soils, presently only simulated by LPJBern, that are proposed to function as a $\mathrm{CH}_{4}$ source or sink depending on the soil moisture level. The participating models use a large diversity of methods to determine MPAs (Fig. 6). We identified the features of the models that we found most strongly controlled the MPAs and visualized the concepts of the models.

The starting points to locate MPAs are either "Prescribed constant wetland extents", "Remotely-sensed inundation" or a "Hydrological model" (Fig. 6). The simplest case of estimating MPAs is where "Prescribed constant wetland extents" are taken from annually, non-varying distribution maps, and are used without modifications. This approach is applied by LPJ-WHyMe and LPJ-Bern (peatlands), which use the northern peatland map from NCSCD (Tarnocai et al., 2007, 2009), and IAP-RAS, which uses the Olson dataset for global MPA location. A similar approach takes seasonally varying "Remotely-sensed inundation" to prescribe MPAs. LPJBern wetlands uses an averaged monthly mean extent from GIEMS, while LPJ-WSL (all experiments except 3) uses the GIEMS dataset without modification. A further step up the 
complexity ladder is LPJ-Bern wetsoils, the most basic wetland extent that uses model output. LPJ-Bern wetsoils uses a "Hydrological model" to derive "Soil moisture" and "Unsaturated" MPAs. "Unsaturated" means that the pore-space in the soil is not completely filled with water. This could be the case when - even though a water table position is calculated - it is below the surface or when the soil moisture is estimated as a homogeneous average over the soil depth and its values do not reach saturation. Next, we include approaches that comprise of "Topography" in addition to "Hydrological model" as an additional factor to locate "Unsaturated" areas (UVic-ESCM). SDGVM uses a similar approach to UVicESCM but simulates "Water table position" before determining "Unsaturated" as well as "Saturated/inundated" MPAs. CLM4Me, DLEM, ORCHIDEE, UW-VIC and LPJ-WSL (Exp. 3) all use "Remotely sensed inundation" (GIEMS) data in their approaches, but they use these data in different ways: e.g. ORCHIDEE guides the mean simulated wetland extent over the 1993-2004 period and CLM4Me uses the GIEMS dataset to invert for parameters that allow the hydrological state (i.e. water table depth and runoff) to be used to determine wetland extent. More details on the use of GIEMS can be found in the description of each model (Sect. 3). Once the "Water table position" is determined, CLM4Me, DLEM, ORCHIDEE, and UW-VIC identify the MPAs that are either "Unsaturated" or "Saturated/inundated" while LPJ-WSL (Experiment 3-opt) determines MPAs which are "Saturated/inundated" only. The UW-VIC model is the most complex model and takes advantage of all of the features included in Fig. 6, using the fractional peatland cover by Sheng et al. (2004) only as maximal boundaries, rather than as a fixed map.

From the conceptual overview (Fig. 6) one can see that the only two models that simulate MPAs without the guidance of other wetland-relevant observations are the UVic-ESCM and the SDGVM. The difference between these two models is that the UVic-ESCM uses only soil moisture (as well as topography) to find "Unsaturated" areas, whereas the SDGVM also calculates the water table position to find "Unsaturated" as well as "Saturated/inundated" areas. As the UVic-ESCM model was designed to identify wetland areas, not specifically MPAs (it presently has no $\mathrm{CH}_{4}$ model), the model uses grid-cell mean unsaturated soil moisture values and terrain slope as a mean of approximating saturated areas.

An additional area of uncertainty that should be noted is the influence of anthropogenic changes to the land surface. Models that explicitly use the GIEMS dataset account for rice agriculture by masking out those regions (Table 3 ) while also implicitly including areas of human alteration such as wetland drainage, conversion to farmland, etc. Models that independently simulate wetland extent will not be sensitive to these alterations and this could lead to an overestimate of wetland area in these regions. Small lakes could also contribute to an overestimated wetland area for some models.
Presently only LPJ-Bern and UW-VIC masks these lakes (Table 3).

\section{2 $\mathrm{CH}_{4}$ flux}

The second variable we analyse in detail is the " $\mathrm{CH}_{4}$ flux" calculation by nine out of the ten participating models the UVic-ESCM does not yet include $\mathrm{CH}_{4}$ fluxes. Figure 7 shows which pools and processes models consider to determine $\mathrm{CH}_{4}$ flux. All models but IAP-RAS base their $\mathrm{CH}_{4}$ production on some kind of carbon flux, where two groups can be distinguished - one that uses "Wetland PFTs" and one that uses "Upland PFTs" to simulate vegetation net primary production (NPP); only DLEM utilizes NPP (and also GPP) simulated by both types of PFTs for $\mathrm{CH}_{4}$ production. The UW-VIC model uses NPP in the algorithm for $\mathrm{CH}_{4}$ production, ORCHIDEE uses a fraction of the most labile of the "Litter + soil C" pool and all remaining models use "Heterotrophic respiration" as the basis for their " $\mathrm{CH}_{4}$ production" (see also Table 5). LPJ-Bern, LPJ-WHyMe and DLEM add "Exudates"-derived carbon to the "Heterotrophic respiration" calculation.

All models calculate $\mathrm{CH}_{4}$ production and half of the models consider "Transport" mechanisms such as ebullition, plant-mediated transport, and diffusion to derive " $\mathrm{CH}_{4}$ fluxes" (Fig. 7, Table 5). This table also gives insight into which models include oxidation of soil-derived $\mathrm{CH}_{4}$ and how they combine production and oxidation rates to simulate the final net $\mathrm{CH}_{4}$ flux. Only three of the models include atmospheric $\mathrm{CH}_{4}$ oxidation (CLM4Me, DLEM, LPJ-Bern wet soils). Thus, we include soil oxidation of atmospheric methane in Table 5 for completeness, but we excluded soil oxidation of atmospheric methane from model results as far as possible in order to compare gross $\mathrm{CH}_{4}$ fluxes. The separation of gross $\mathrm{CH}_{4}$ fluxes and atmospheric $\mathrm{CH}_{4}$ uptake fluxes was not completely feasible in CLM4Me as the $\mathrm{CH}_{4}$ uptake occurs implicitly in the reaction-transport solution, although for Melton et al. (2013) an estimate was determined to allow better comparison between models. Across the models, the complexity of equations for $\mathrm{CH}_{4}$ production covers a wide range. The IAP-RAS model is the simplest model relating $\mathrm{CH}_{4}$ production only to temperature, whereas all other models use some estimate of the available carbon flux rate. All but two models (IAP-RAS and LPJ-WSL) include some kind of soil-derived $\mathrm{CH}_{4}$ oxidation, which can be as simple as reducing production by a fixed fraction (SDGVM) or by including up to five different terms in the equation (Table 5).

\subsection{Methane producing area and methane flux}

Mean annual maximum extent of wetland area and mean annual $\mathrm{CH}_{4}$ fluxes for Experiment 1-equil are shown in Fig. 8. Total MPAs and $\mathrm{CH}_{4}$ emissions for each model are listed in the bottom left corner of each sub-figure. Two of the models are regional models (LPJ-WHyMe and UW-VIC), the rest 
are global models in which the UVic-ESCM does not simulate $\mathrm{CH}_{4}$ fluxes. CLM4Me, DLEM, LPJ-Bern (without mineral soils), LPJ-WSL, and ORCHIDEE share similar wetland distributions due to their varying degrees of reliance on remotely sensed inundation data (see Fig. 6). The similarity of approaches is also reflected in the total MPA of these models (CLM4Me: $6.8 \times 10^{6}$, DLEM: $7.9 \times 10^{6}$, LPJBern without mineral soils: $7.9 \times 10^{6}$, LPJ-WSL: $7.4 \times 10^{6}$, and ORCHIDEE: $9.2 \times 10^{6} \mathrm{~km}^{2}$ ). Two models (IAP-RAS and LPJ-Bern with wet mineral soils) stand out visually because of their large areas of 80-100\% MPA per grid cell. The IAP-RAS model uses a binary approach - either a grid cell is a wetland or it is not - resulting in a total MPA of $20.3 \times 10^{6} \mathrm{~km}^{2}$, which is an entirely prescribed amount. Given the definition of the wet mineral soils as $\mathrm{CH}_{4}$ source, the LPJ-Bern wet mineral soils map should be interpreted as a map of "potential $\mathrm{CH}_{4}$ emissions in at least one month per year". Since LPJ-Bern does not use a sub-grid-cell hydrology for wet mineral soils to estimate the $\mathrm{CH}_{4}$ production capacity, the wet mineral soils component of LPJ-Bern is also a binary approach. However, the extent of wet mineral soils in a given grid cell can be reduced by peatland area and inundated area so that they jointly sum to $100 \%$, but as soon as a grid cell qualifies as wet mineral soils, the MPA of that grid cell is $100 \%$. This approach leads to the largest total MPA of $76.6 \times 10^{6} \mathrm{~km}^{2}$ of the WETCHIMP models.

The only two models that use an explicit water balance scheme to simulate wetland extent without relying on wetland or inundation datasets are the SDGVM and the UVicESCM (Fig. 8). They show a similar spatial distribution but differ notably in Eastern Siberia, the western United States and northern Canada. SDGVM uses soil moisture content to first diagnose water table position and then MPAs, whereas UVic-ESCM uses soil moisture directly to derive MPAs. The differences between these two models could be related to parameterization of permafrost (present in UVic-ESCM, but absent in SDGVM) and other soil physics or hydrology parameters, i.e. hydraulic conductivity, porosity, etc. Further, the percentages of grid cells covered by wetlands are generally higher for SDGVM than for the UVic-ESCM leading to a higher overall wetland area of $34.9 \times 10^{6} \mathrm{~km}^{2}$ vs $14.9 \times 10^{6} \mathrm{~km}^{2}$, respectively.

Of the two regional models, LPJ-WHyMe uses a fixed peatland distribution (Fig. 8e) whereas the UW-VIC model uses the most sophisticated method of all participating models to simulate saturated and unsaturated wetland areas in the West Siberian Lowlands (Fig. 8j). A comparison focused on the West Siberian Lowlands is planned to evaluate the differences between a highly regionalized model like the UW-VIC model and the rest of the WETCHIMP models (T. Bohn, personal communication, June 2012).

Simulated $\mathrm{CH}_{4}$ fluxes of nine of the participating models are shown on the right hand side in Fig. 8. Methane fluxes ranged from 0 to over $250 \mathrm{~g} \mathrm{CH}_{4} \mathrm{~m}^{-2}$ of wetland $\mathrm{yr}^{-1}$ with CLM4Me, DLEM, LPJ-WSL, and ORCHIDEE showing

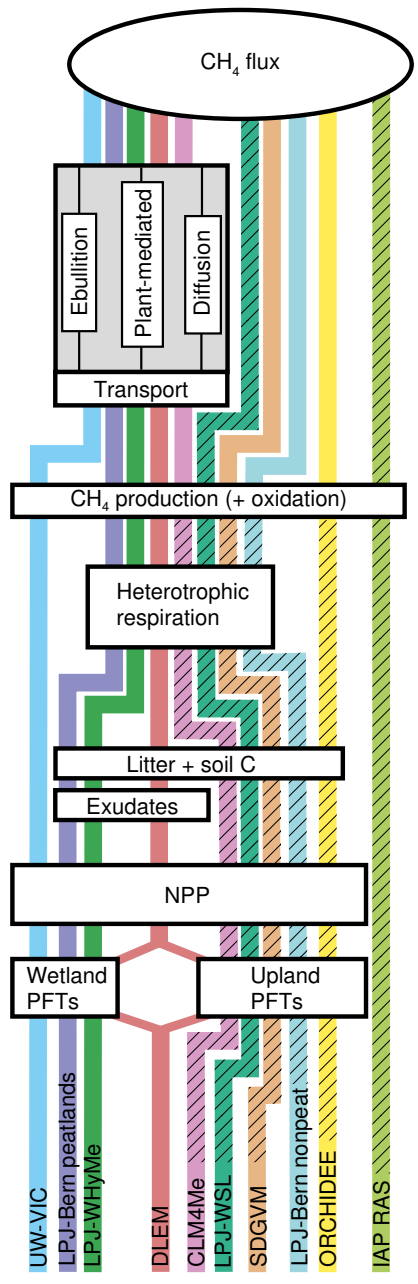

Fig. 7. Conceptual overview of the pathways from the carbon source to " $\mathrm{CH}_{4}$ flux" $\left(\mathrm{CH}_{4}\right.$ flux per $\mathrm{m}^{2}$ of wetland) in the participating models. Each model (and in some cases, version) is represented by a different colour. The flow of a particular model starts with the model's name. The hatching of the lines indicates that the $\mathrm{CH}_{4}$ model is not influenced by wetland hydrology (beyond changes in extent). "Wetland PFTs" means that the model uses wetlandspecific PFTs, whereas "Upland PFTs" indicates that the model uses the already existing PFTs used for upland ecosystems. "NPP" stands for net primary production, "Exudates" are root exudates carbon pool. All models but the IAP-RAS model use NPP as a precursor of the carbon used directly in $\mathrm{CH}_{4}$ production or indirectly in $\mathrm{CH}_{4}$ production by estimating "Litter and Soil C", "Exudates", and "Heterotrophic respiration". The models then calculate " $\mathrm{CH}_{4}$ production" and the oxidation based on the equations given in Table 5. Some models include the effect of "Transport" mechanisms explicitly, whereas others include transport only implicitly by either producing less $\mathrm{CH}_{4}$ or oxidizing it before emitting it to the atmosphere. All models use some sort of temperature dependence when calculating NPP, heterotrophic respiration, and/or $\mathrm{CH}_{4}$ production. In this figure, "LPJ-Bern nonpeat" includes both wetlands and wetsoils, which also incorporate plant exudates (graphical simplification). 


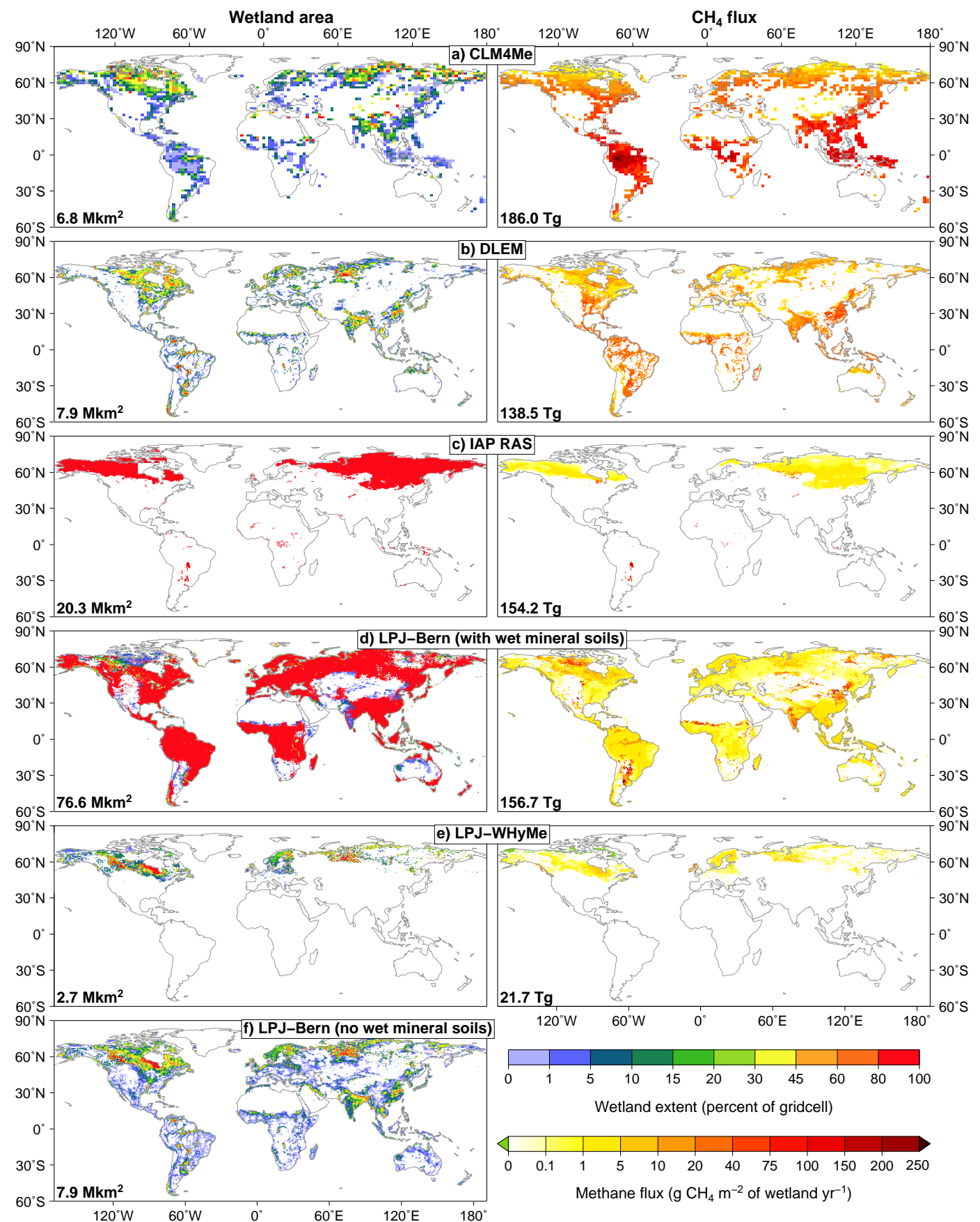

Fig. 8. Mean annual maximum extent of prescribed or simulated wetland area and mean annual $\mathrm{CH}_{4}$ flux for Experiment 1-equil over the 1901-1931 period. Global total wetland area $\left(\mathrm{Mkm}^{2}=\right.$ Million $\left.\mathrm{km}^{2}\right)$ and $\mathrm{CH}_{4}$ emissions $\left(\mathrm{Tg}=\mathrm{Tg} \mathrm{CH}_{4}\right.$ per year) have been added to each plot.

widespread high fluxes (Fig. 8a, b, g, h) and IAP-RAS, LPJBern, LPJ-WHyMe, SDGVM, and UW-VIC showing low fluxes (Fig. 8c, d, e, i, j). Of the five models that show widespread high fluxes, three base their $\mathrm{CH}_{4}$ flux on upland PFTs (CLM4Me, LPJ-WSL, ORCHIDEE), and one on both wetland and upland PFTs (DLEM) (Fig. 7). Of the four models that show low $\mathrm{CH}_{4}$ fluxes, three rely on wetland PFTs (LPJ-Bern, LPJ-WHyMe, and UW-VIC), one on upland PFTs (SDGVM) and one does not rely on PFTs at all (IAP-RAS). This could indicate a general tendency to higher $\mathrm{CH}_{4}$ fluxes when upland PFTs instead of wetland PFTs are used to simulate NPP. Some of the models show higher fluxes 


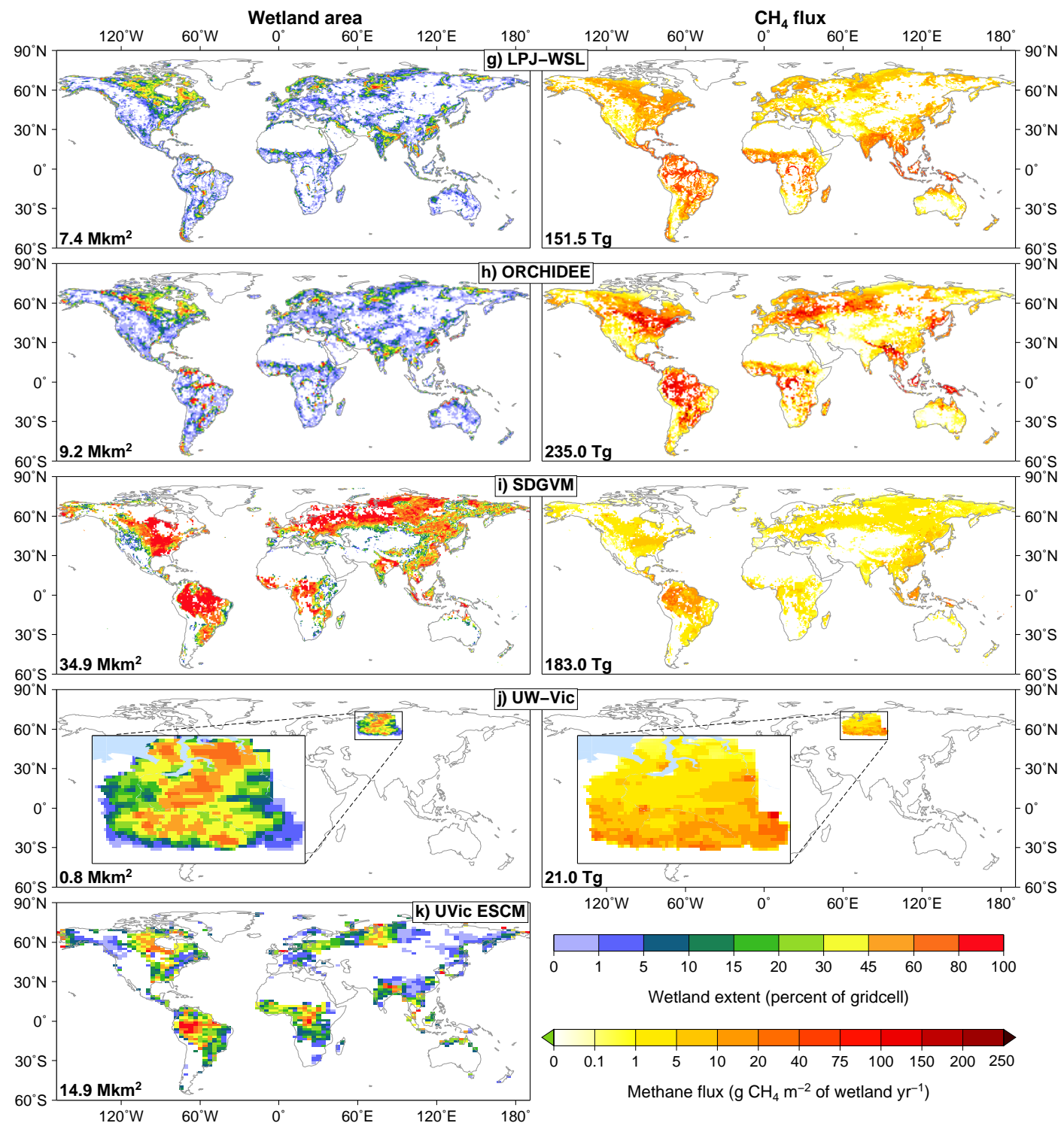

Fig. 8. Continued.

in the tropics than in the extra-tropics (CLM4Me, IAP-RAS, SDGVM), whereas others show equally high fluxes (DLEM, LPJ-Bern, LPJ-WSL, ORCHIDEE), which may be linked to the model-inherent temperature sensitivities of, e.g. NPP, heterotrophic respiration or $\mathrm{CH}_{4}$ production, but without specific parameter sensitivity studies it is impossible to evaluate where the differences arise from.

The patterns of $\mathrm{CH}_{4}$ fluxes do not always match the pattern of wetland distribution (e.g. compare wetland area and $\mathrm{CH}_{4}$ fluxes for the Amazon from CLM4Me). Total $\mathrm{CH}_{4}$ emissions for a grid cell are calculated as the product of fluxes and wetland area (except for CLM4Me, which also considers production in upland soils). Therefore, models may simulate similar global $\mathrm{CH}_{4}$ emissions with completely different MPAs and $\mathrm{CH}_{4}$ fluxes (e.g. CLM4Me: $186 \mathrm{Tg} \mathrm{CH}_{4} \mathrm{yr}^{-1}$ vs SDGVM: $183 \mathrm{Tg} \mathrm{CH}_{4} \mathrm{yr}^{-1}$, or IAPRAS: $154.2 \mathrm{Tg} \mathrm{CH}_{4} \mathrm{yr}^{-1}$ vs LPJ-Bern: $156.6 \mathrm{Tg} \mathrm{CH}_{4} \mathrm{yr}^{-1}$ vs LPJ-WSL: $151.5 \mathrm{Tg} \mathrm{CH}_{4} \mathrm{yr}^{-1}$ ) (Fig. 8). The comparability of these simulated global $\mathrm{CH}_{4}$ emissions emphasizes the fact that most models are tuned to some degree towards a global total $\mathrm{CH}_{4}$ emissions value, which allows the MPAs to vary more between the models than global $\mathrm{CH}_{4}$ emissions. As highlighted in Melton et al. (2013), the fact that the models agree fairly well on global $\mathrm{CH}_{4}$ emissions with very different MPAs and $\mathrm{CH}_{4}$ fluxes underlines the importance of regional-scale observational estimates to constrain this dichotomy. 
Table 6. Explanation of variable names used in Table 5.

\begin{tabular}{|c|c|}
\hline Variable name & Description \\
\hline $\mathrm{C}_{\text {labile }}$ & labile carbon pool \\
\hline$O_{\text {air }}$ & soil oxidation of atmospheric $\mathrm{CH}_{4}$, i.e. $\mathrm{CH}_{4}$ uptake \\
\hline$O_{\text {air,max }}$ & maximum soil oxidation of atmospheric $\mathrm{CH}_{4}$ rate \\
\hline$O_{\text {soil }}$ & oxidation in the soil pore water \\
\hline$O_{\text {soil.max }}$ & maximum oxidation rate in the soil pore water \\
\hline$O_{\text {trans }}$ & oxidation associated with transport through plants \\
\hline$O_{\text {trans, } \max }$ & maximum oxidation associated with transport through plants \\
\hline$O_{\max }$ & maximum oxidation rate \\
\hline$P_{\max }$ & maximum $\mathrm{CH}_{4}$ production \\
\hline$Q_{10}$ & factor describing dependence on temperature \\
\hline$R_{\text {hetr }}$ & heterotrophic respiration \\
\hline$R_{0}$ & $\mathrm{CH}_{4}$ production rate \\
\hline$f_{\left[\mathrm{CH}_{4}\right]}$ & function of pore water $\mathrm{CH}_{4}$ concentration \\
\hline$f_{\mathrm{atm}}\left[\mathrm{CH}_{4}\right]$ & function of atmospheric $\mathrm{CH}_{4}$ concentration \\
\hline$f_{\text {ecosys }}$ & function of ecosystem type \\
\hline$f_{\mathrm{GPP}}$ & function of the ratio of monthly to annual net primary production (NPP) \\
\hline$f_{\left[\mathrm{O}_{2}\right]}$ & $\begin{array}{l}\text { function of pore water } \mathrm{O}_{2} \text { concentration, determined by rate of } \mathrm{O}_{2} \\
\text { diffusion through soil water and aerenchyma }\end{array}$ \\
\hline$f_{\mathrm{pE}}$ & function of alternative electron acceptors \\
\hline$f_{\mathrm{pH}}$ & function of $\mathrm{pH}$ value \\
\hline$f_{\text {planttrans }}$ & function of plant-mediated $\mathrm{CH}_{4}$ transport \\
\hline$f_{\text {root }}$ & function of vertical root distribution \\
\hline$f_{\text {soil }}$ & function of soil type \\
\hline$f_{T}$ & function of temperature \\
\hline$f_{\Theta}$ & function of soil moisture \\
\hline$f_{\text {transport }}$ & function of $\mathrm{CH}_{4}$ transport \\
\hline$f_{\mathrm{WTP}}$ & function of water table position \\
\hline$r_{\mathrm{CH} 4: \mathrm{C}}$ & fraction of $\mathrm{C}$ converted to $\mathrm{CH}_{4}$ \\
\hline$r_{\mathrm{O}_{2}}$ & fraction of $\mathrm{O}_{2}$ used for $\mathrm{CH}_{4}$ oxidation \\
\hline
\end{tabular}

\section{Summary and conclusions}

WETCHIMP is the first multi-model comparison of wetland extent and wetland $\mathrm{CH}_{4}$ emissions. Our analysis demonstrates how diverse modelling approaches, wetland definitions, and wetland extent can be, while still leading to comparable values of global $\mathrm{CH}_{4}$ emissions. In terms of modelling $\mathrm{CH}_{4}$ producing areas (MPAs), there are three main approaches: (i) the fixed MPA (IAP-RAS, LPJ-Bern (peatlands and wetlands), LPJ-WHyMe), (ii) the guided MPA (CLM4Me, DLEM, LPJ-WSL, ORCHIDEE, UW-VIC) and (iii) the fully simulated MPA (UVic-ESCM, SDGVM, LPJBern wetsoils). Total MPA can vary significantly between models depending on their definitions, which also influences $\mathrm{CH}_{4}$ fluxes, but does not have as much impact on the global $\mathrm{CH}_{4}$ emissions. Achieving similar global $\mathrm{CH}_{4}$ emissions with very different MPA distributions also means that the $\mathrm{CH}_{4}$ fluxes between the models differ greatly. A wide range of parameterization complexity is used to simulate $\mathrm{CH}_{4}$ fluxes in the participating models, which influences not just the present day flux but also its sensitivity to climate factors.
Each individual model's approach needs to be considered carefully when interpreting results, especially past and future climate change experiments or sensitivity experiments such as those that were conducted as part of WETCHIMP (Melton et al., 2013). There are several factors that need to be kept in mind: a fixed wetland distribution as used by some models or a seasonally varying distribution based on presently observed patterns is unlikely to be representative of past or future conditions. Another limitation is the absence of wetland specific PFTs in most models. Models that lack wetland specific PFTs (i.e. CLM4Me, LPJ-WSL, SDGVM, LPJ-Bern non-peatland, ORCHIDEE, IAP-RAS) may overestimate NPP due to an unrealistic lack of plant stress that would be caused by inundation or nutrient limitation. We expect these models to show different responses to changes in temperature, precipitation and $\mathrm{CO}_{2}$ fertilization than the models that include wetland specific PFTs (i.e. DLEM, LPJ-WHyMe, LPJ-Bern peatlands, UW-VIC). For example, changes in precipitation will affect wetland specific PFTs that grow under inundated conditions differently than upland plants. Also, the effect of $\mathrm{CO}_{2}$ fertilization on wetland plants is still unclear (Berendse et al., 2001; Heijmans et al., 2001, 2002a,b; Boardman et al., 
2011) and therefore wetland NPP under $\mathrm{CO}_{2}$ fertilization calculated by models that include wetland specific PFTs remains highly uncertain.

There are features that are still missing, or are crudely represented, in almost all of the models, partially due to the difficulties of simulating small-scale processes in large-scale models. Such features include (i) lateral transport of water and groundwater dynamics within (beyond the assumptions of the TOPMODEL formulation) and between grid cells, and explicit treatments of floodplains and mangroves; (ii) plant nutrients (nitrogen, phosphorus and sulphur) and their interactions (presently only SDGVM, DLEM, and CLM4Me include carbon-nitrogen interactions); (iii) microtopographical features such as lawns, hollows or hummocks and their impacts upon overall $\mathrm{CH}_{4}$ dynamics; (iv) vertically resolved carbon pools and soil organic matter remineralization modelling; (v) permafrost-preserved carbon; (vi) feedbacks between peat or carbon dynamics and thermal and hydrological processes in soil; (vii) hydrology affected by thawing permafrost; (viii) wetland specific vegetation (improvements for boreal peatlands, introduction of tropical wetland PFTs); and (ix) anthropogenic disturbance (such as wetland drainage) and management (such as dams and reservoirs).

WETCHIMP provides a the first multi-model platform to explore the current knowledge, recent improvements, and necessary future developments of models simulating wetland extent and wetland $\mathrm{CH}_{4}$ emissions. The design of future iterations of WETCHIMP will be focused on analysing and understanding the different uncertainties and sensitivities of participating models with the goal of greatly improving the performance of the models for both wetland and wetland $\mathrm{CH}_{4}$ modelling. The simulations conducted in WETCHIMP are available (http://arve.epfl.ch/pub/wetchimp, please contact J. R. Melton for immediate access) and their use is encouraged to advance research in this area.

Acknowledgements. The authors are grateful to the COST Action ES0805 TERRABITES for providing support for the WETCHIMP workshop. We thank Sylvia Houston and Olga Petrikova for assistance with organizing the project meeting and Kristen Krumhardt for assistance producing the figures. J. R. M. was supported by the Swiss Ministry for Research and Education (grant C09.0054). J. O. K. acknowledges support from the Swiss National Science Foundation (grants PP0022_119049 and PP00P2_139193). The contributions of W. J. R. and Z. M. S. were supported by the Director, Office of Science, Office of Biological and Environmental Research, Climate and Environmental Science Division, of the US Department of Energy under Contract No. DE-AC02-05CH11231 to Berkeley Lab (IMPACTS and C-Climate Uncertainties projects). The contributions of T. J. B. and D. P. L. were supported by NASA's ROSES program, grant NNX08AH97G. The contribution of Z. C. Y. was supported by a US NSF grant (ARC-1107981) and a grant from The Max Planck Society (Germany). A. V. E. and S. N. D. were supported by the the President of Russia grant 5467.2012.5, by the Russian Foundation for Basic Research, and by the programs of the Russian Academy of Sciences. The contributions of R. S. and
S. Z. were supported by the Swiss National Science Foundation and by the European Research Council advanced grant MATRICs (ERC grant agreement no. 226172) under the European Community's Seventh Framework Programme. P. O. H. is supported by a NERC UK grant NE/I010912/1 and previously through NERC UK/INSU France QUEST-DESIRE project. E. L. H. was supported by ETH Competence Center Environment and Sustainability's grant MAIOLICA. We also thank Steve Frolking and one anonymous reviewer for their comments which have improved our manuscript.

Edited by: D. Roche

\section{References}

Aselman, I. and Crutzen, P. J.: Global distribution of natural freshwater wetlands and rice paddies, and their net primary productivity, seasonality and possible methane emissions, J. Atmos. Chem., 8, 307-358, 1989.

Avis, C. A., Weaver, A. J., and Meissner, K. J.: Reduction in areal extent of high-latitude wetlands in response to permafrost thaw, Nat. Geosci., 4, 444-448, 2011.

Bartalev, S. A., Belward, A. S., Erchov, D. V., and Isaev, A. S.: A new SPOT4-VEGETATION derived land cover map of Northern Eurasia, Int. J. Remote Sens., 24, 1977-1982, 2003.

Batjes, N. H.: A world dataset of derived soil properties by FAOUNESCO soil unit for global modelling, Soil Use Manage., 13, 9-16, 1997.

Beerling, D. J. and Woodward, F. I.: Vegetation and the Terrestrial Carbon Cycle: Modelling the first 400 Million Years, Cambridge University Press, Cambridge, 2001.

Beerling, D. J., Fox, A., Stevenson, D. S., and Valdes, P. J.: Enhanced chemistry-climate feedbacks in past greenhouse worlds, P. Natl. Acad. Sci. USA, 108, 9770-9775, doi:10.1073/pnas.1102409108, 2011.

Berendse, F., Breemen, N. V., Rydin, H., Buttler, A., Heijmans, M., Hoosbeek, M. R., Lee, J. A., Mitchell, E., Saarinen, T., Vasander, H., and Wallen, B.: Raised atmospheric $\mathrm{CO}_{2}$ levels and increased $\mathrm{N}$ deposition cause shifts in plant species composition and production in Sphagnum bogs, Glob. Change Biol., 7, 591598, 2001.

Beven, K. J. and Kirkby, M. J.: A physically based, variable contributing area model of basin hydrology, Hydrol. Sci. J., 24, 4369, 1979.

Boardman, C. P., Gauci, V., Watson, J. S., Blake, S., and Beerling, D. J.: Contrasting wetland $\mathrm{CH}_{4}$ emission responses to simulated glacial atmospheric $\mathrm{CO}_{2}$ in temperate bogs and fens, New Phytol., 192, 898-911, 2011.

Bohn, T. J. and Lettenmaier, D. P.: Systematic biases in large-scale estimates of wetland methane emissions arising from water table formulations, Geophys. Res. Lett., 37, L22401, doi:10.1029/ 2010GL045450 2010.

Bohn, T. J., Lettenmaier, D. P., Sathulur, K., Bowling, L. C., Podest, E., McDonald, K. C., and Friborg, T.: Methane emissions from western Siberian wetlands: heterogeneity and sensitivity to climate change, Environ. Res. Lett., 2, 259-268, 2007.

Bowling, L. C. and Lettenmaier, D. P.: Modeling the effects of lakes and wetlands on the water balance of Arctic environments, J. Hydrometeorol., 11, 276-295, 2010. 
Cao, M. K., Marshall, S., and Gregson, K.: Global carbon exchange and methane emissions from natural wetlands: application of a process-based model, J. Geophys. Res., 101, 14399-14414, 1996.

Chen, G., Tian, H., Zhang, C., Liu, M., Ren, W., Zhu, W., Chappelka, A., Prior, S. A., and Lockaby, G.: Drought in the southern United States over the last century: variability and its impacts on terrestrial ecosystem productivity and carbon storage, Clim. Change, 114, 379-397, doi:10.1007/s10584-012-0410-z, 2012.

Cherkauer, K. A. and Lettenmaier, D. P.: Hydrologic effects of frozen soils in the upper Mississippi River basin, J. Geophys. Res.-Atmos., 104, 19599-19610, 1999.

Christensen, T. R. and Cox, P.: Response of methane emission from arctic tundra to climatic change: results from a model simulation, Tellus B, 47, 301-309, 1995.

Christensen, T. R., Prentice, I. C., Kaplan, J., Haxeltine, A., and Sitch, S.: Methane flux from northern wetlands and tundra - an ecosystem source modelling approach, Tellus B, 48, 652-661, 1996.

Coe, M. T.: Simulating continental surface waters: an application to Holocene northern Africa, J. Clim., 10, 1680-1689, doi:10.1175/15200442(1997)010\%3C1680:SCSWAA\%3E2.0.CO;2, 1997.

Coe, M. T.: A linked global model of terrestrial hydrologic processes: simulation of modern rivers, lakes, and wetlands, J. Geophys. Res., 103, 8885-8899, 1998.

Cox, P.: Description of the TRIFFID dynamic global vegetation model, Hadley Centre, Met Office, Technical Note 24, 2001.

Curry, C. L.: Modelling the soil consumption of atmospheric methane at the global scale, Global Biogeochem. Cy., 21, gB4012, doi:10.1029/2006GB002818, 2007.

Curry, C. L.: The consumption of atmospheric methane by soil in a simulated future climate, Biogeosciences, 6, 2355-2367, doi:10.5194/bg-6-2355-2009, 2009.

Dentener, F., Drevet, J., Lamarque, J., Bey, I., Eickhout, B., Fiore, A., Hauglustaine, D., Horowitz, L., Krol, M., and Kulshrestha, U.: Nitrogen and sulfur deposition on regional and global scales: a multimodel evaluation, Global Biogeochem. Cy., 20, gB4003, doi:10.1029/2005GB002672, 2006.

ETOPO: 2-minute gridded global relief data (ETOPO2v2), US Department of Commerce, National Oceanic and Atmospheric Administration, National Geophysical Data Center, available at: http://www.ngdc.noaa.gov/mgg/fliers/06mgg01.html (last access: 14 August 2012), 2006.

FAO/IIASA/ISRIC/ISSCAS/JRC: Harmonized World Soil Database (version 1.1), Tech. rep., FAO, Rome, Italy and IIASA, Laxenburg, Austria, 2009.

Farouki, O. T.: The thermal-properties of soils in cold regions, Cold Reg. Sci. Technol., 5, 67-75, 1981.

Farr, T. G. and Kobrick, M.: Shuttle radar topography mission produces a wealth of data, EOS Trans. Am. Geophys. Union, 81, 583-585, 2000.

Fries, R. D., Hansen, M., Townshend, J., and Sohlberg, R.: Global land cover classifications at $8 \mathrm{~km}$ spatial resolution: the use of training data derived from Landsat imagery in decision tree classifiers, Int. J. Remote Sens., 19, 3141-3168, 1998.

Frolking, S., Roulet, N. T., Moore, T. R., Lafleur, P. M., Bubier, J. L., and Crill, P. M.: Modeling seasonal to annual carbon balance of Mer Bleue Bog, Ontario, Canada, Global Bio- geochem. Cy., 16, 4-1-4-21, doi:10.1029/2001GB001457 2002.

Fung, I. Y., John, J., Lerner, J., Matthews, E., Prather, M., Steele, L. P., and Fraser, P. J.: Three-dimensional model synthesis of the global methane cycle, J. Geophys. Res., 96, 13033-13065, 1991.

Gedney, N., Cox, P. M., and Huntingford, C.: Climate feedback from wetland methane emissions, Geophys. Res. Lett., 31, L20503, doi:10.1029/2004GL020919, 2004.

Gerber, S., Joos, F., Brugger, P., Stocker, T., Mann, M., Sitch, S., and Scholze, M.: Constraining temperature variations over the last millennium by comparing simulated and observed atmospheric $\mathrm{CO}_{2}$, Clim. Dynam., 20, 281-299, doi:10.1007/s00382002-0270-8, 2003.

Gerten, D., Schaphoff, S., Haberlandt, U., Lucht, W., and Sitch, S.: Terrestrial vegetation and water balance - hydrological evaluation of a dynamic global vegetation model, J. Hydrol., 286, 249270, 2004.

Glagolev, M. V., Kleptsova, I. E., Filippov, I. V., Kazantsev, V. S., Machida, T., and Maksyutov, S.: Methane emissions from subtaiga mires of Western Siberia: the Standard Model Bc5, Moscow Univ. Soil Sci. Bull., 65, 86-93, 2010.

Global Soil Data Task Group: Global gridded surfaces of selected soil characteristics (IGBP-DIS), Oak Ridge National Laboratory Distributed Active Archive Center, Oak Ridge, Tennessee, USA, available at: http://www.daac.ornl.gov (last access: 14 August 2012), 2000.

Hayakawa, Y. S., Oguchi, T., and Lin, Z.: Comparison of new and existing global digital elevation models: ASTER G-DEM and SRTM-3, Geophys. Res. Lett., 35, 19599-19610, 2008.

Heijmans, M. M. P. D., Arp, W. J., and Berendse, F.: Effects of elevated $\mathrm{CO}_{2}$ and vascular plants on evapotranspiration in bog vegetation, Glob. Change Biol., 7, 817-827, 2001.

Heijmans, M. M. P. D., Klees, H., and Berendse, F.: Competition between Sphagnum magellanicum and Eriophorum angustifolium as affected by raised $\mathrm{CO}_{2}$ and increased $\mathrm{N}$ deposition, Oikos, 97, 415-425, 2002a.

Heijmans, M. M. P. D., Klees, H., de Visser, W., and Berendse, F.: Response of a Sphagnum bog plant community to elevated $\mathrm{CO}_{2}$ and N supply, Plant Ecol., 162, 123-134, 2002b.

Hodson, E. L., Poulter, B., Zimmermann, N. E., Prigent, C., and Kaplan, J. O.: The El Niño-Southern Oscillation and wetland methane interannual variability, Geophys. Res. Lett., 38, L08810, doi:10.1029/2011GL046861, 2011.

Hopcroft, P. O., Valdes, P. J., and Beerling, D. J.: Simulating idealized Dansgaard-Oeschger events and their potential impacts on the global methane cycle, Quaternary Sci. Rev., 30, 3258-3268, 2011.

Hungate, B. A., Dukes, J. S., Shaw, M. R., Luo, Y. Q., and Field, C. B.: Nitrogen and climate change, Science, 302, 1512 1513, 2003.

IPCC: Emissions Scenarios, Special Report of the Intergovernmental Panel on Climate Change, Tech. Rep., Cambridge University Press, Cambridge UK, 2000.

ISLSCP-II: Global Gridded Surfaces of Selected Soil Characteristics for the International Satellite Land Surface Climatology Project (ISLSCP) Initiative II Data Collection, Global Soil Data Task Group, Oak Ridge, Tennessee, USA, available at: https: //daac.ornl.gov (last access: 14 August 2012), 2009. 
Jones, P. D. and Harris, I.: CRU Time Series (TS) high resolution gridded datasets, University of East Anglia Climatic Research Unit (CRU), available at: http://badc.nerc.ac.uk/view/badc.nerc. ac.uk_ATOM_dataent_1256223773328276 (last access: $28 \mathrm{Au}-$ gust 2012), 2008.

Joos, F., Gerber, S., Prentice, I. C., Otto-Bliesner, B. L., and Valdes, P. J.: Transient simulations of Holocene atmospheric carbon dioxide and terrestrial carbon since the Last Glacial Maximum, Global Biogeochem. Cy., 18, GB2002, doi:10.1029/2003GB002156, 2004.

Kaplan, J. O.: Wetlands at the Last Glacial Maximum: Distribution and methane emissions, Geophys. Res. Lett., 29, 1079, doi:10.1029/2001GL013366, 2002.

Knorr, W.: Annual and interannual $\mathrm{CO}_{2}$ exchanges of the terrestrial biosphere: process-based simulations and uncertainties, Global Ecol. Biogeogr., 9, 225-252, 2000.

Koven, C. D., Ringeval, B., Friedlingstein, P., Ciais, P., Cadule, P., Khvorostyanov, D., Krinner, G., and Tarnocai, C.: Permafrost carbon-climate feedbacks accelerate global warming, P. Natl. Acad. Sci., 108, 14769-14774, 2011.

Krinner, G.: Impact of lakes and wetlands on boreal climate, J. Geophys. Res., 108, 4520,doi:10.1029/2002JD002597, 2003.

Krinner, G., Viovy, N., de Noblet-Ducoudre, N., Ogee, J., Polcher, J., Friedlingstein, P., Ciais, P., Sitch, S., and Prentice, I. C.: A dynamic global vegetation model for studies of the coupled atmosphere-biosphere system, Global Biogeochem. Cy., 19, 941-962, 2005.

Kudryavtsev, V. A., Garagula, L. S., Kondratiyeva, K. A., and Melamed, V. E.: Frost Forecasting in Geological Engineering Investigations, CRREL, Hanover, NH, 1977.

Lawrence, D. M., Oleson, K. W., Flanner, M. G., Thornton, P. E., Swenson, S. C., Lawrence, P. J., Zeng, X., Yang, Z.-L., Levis, S., Sakaguchi, K., Bonan, G. B., and Slate, A. G.: Parameterization improvements and functional and structural advances in version 4 of the Community Land Model, J. Adv. Model. Earth. Sys., 3, M03001, doi:10.1029/2011MS000045, 2011.

Lawrence, P. J. and Chase, T. N.: Representing a new MODIS consistent land surface in the Community Land Model (CLM 3.0), J. Geophys. Res., 112, G01023, doi:10.1029/2006JG000168, 2007.

Leff, B., Ramankutty, N., and Foley, J.: Geographic distribution of major crops across the world, Global. Biogeochem. Cy., 18, GB1009, doi:10.1029/2003GB002108, 2004.

Lehner, B. and Döll, P.: Development and validation of a global database of lakes, reservoirs and wetlands, J. Hydrol., 296, 1-22, 2004.

Letts, M. G., Roulet, N. T., Comer, N. T., Skarupa, M. R., and Verseghy, D. L.: Parametrization of peatland hydraulic properties for the Canadian Land Surface Scheme, Atmos. Ocean, 38, 141-160, 2000.

Liang, X., Lettenmaier, D. P., Wood, E. F., and Burges, S. J.: A simple hydrologically based model of land-surface water and energy fluxes for general-circulation models, J. Geophys. Res., 99, 14415-14428, 1994.

Liu, M., Tian, H., Yang, Q., Yang, J., Song, X., Lohrenz, S. E., and Cai, W.: Long-term trends in evapotranspiration and runoff over the drainage basins of the Gulf of Mexico during 1901-2008, Water Resour. Res., 49, 1-25, 10.1002/wrcr.20180, 2013.

Matthews, E. and Fung, I. Y.: Methane emission from natural wetlands: Global distribution, area, and environmental characteris- tics of sources, Global Biogeochem. Cy., 1, 61-86, 1987.

Meehl, G. A., Stocker, T. F., Collins, W. D., Friedlingstein, P., Gaye, A. T., Gregory, J. M., Kitoh, A., Knutti, R., Murphy, J. M., Noda, A., Raper, S. C. B., Watterson, I. G., Weaver, A. J., and Zhao, Z.-C.: Global climate projections, in: Climate change 2007: The physical science basis. Contribution of Working Group I to the Fourth Assessment Report of the Intergovernmental Panel on Climate Change, edited by: Solomon, S., Qin, D., Manning, M., Chen, Z., Marquis, M., Averyt, K. B., Tignor, M., and Miller, H. L., chap. 10, Cambridge University Press, Cambridge, UK and New York, NY, USA, 747-846, 2007.

Meissner, K. J., Weaver, A. J., Matthews, H. D., and Cox, P. M.: The role of land surface dynamics in glacial inception: a study with the UVic Earth System Model, Clim. Dynam., 21, 515-537, 2003.

Melton, J. R., Wania, R., Hodson, E. L., Poulter, B., Ringeval, B., Spahni, R., Bohn, T., Avis, C. A., Beerling, D. J., Chen, G., Eliseev, A. V., Denisov, S. N., Hopcroft, P. O., Lettenmaier, D. P., Riley, W. J., Singarayer, J. S., Subin, Z. M., Tian, H., Zürcher, S., Brovkin, V., van Bodegom, P. M., Kleinen, T., Yu, Z. C., and Kaplan, J. O.: Present state of global wetland extent and wetland methane modelling: conclusions from a model intercomparison project (WETCHIMP), Biogeosciences, 10, 753788, doi:10.5194/bg-10-753-2013, 2013.

Mitchell, T. D. and Jones, P. D.: An improved method of constructing a database of monthly climate observations and associated high-resolution grids, Int. J. Climatol., 25, 693-712, 2005.

Mokhov, I. I., Eliseev, A. V., and Denisov, S. N.: Model diagnostics of variations in methane emissions by wetlands in the second half of the 20th century based on reanalysis data, Doklady Earth Sci., 417, 1293-1297, doi:10.1134/S1028334X07080375, 2007.

Myneni, R. B., Hoffman, S., Knyazikhin, Y., Privette, J. L., Glassy, J., Tian, Y., Wang, Y., Song, X., Zhang, Y., Smith, G. R., Lotsch, A., Friedl, M., Morisette, J. T., Votava, P., Nemani, R. R., and Running, S. W.: Global products of vegetation leaf area and fraction absorbed PAR from year one of MODIS data, Remote Sens. Environ., 83, 214-231, 2002.

Niu, G., Yang, Z., Dickinson, R. E., and Gulden, L. E.: A simple TOPMODEL-based runoff parameterization (SIMTOP) for use in global climate models, J. Geophys. Res., 110, D21106, doi:10.1029/2005JD006111, 2005.

Oleson, K. W., Niu, G. -Y., Yang, Z. -L., Lawrence, D. M., Thornton, P. E., Lawrence, P. J., Stöckli, R., Dickinson, R. E., Bonan, G. B., Levis, S., Dai, A., and Qian, T.: Improvements to the Community Land Model and their impact on the hydrological cycle, J. Geophys. Res. Biogeosci., 113, 2156-2202, doi:10.1029/2007JG000563, 2008.

Papa, F., Prigent, C., Durand, F., and Rossow, W. B.: Wetland dynamics using a suite of satellite observations: a case study of application and evaluation for the Indian Subcontinent, Geophys. Res. Lett., 33, L08401, doi:10.1029/2006GL025767, 2006.

Papa, F., Prigent, C., and Rossow, W. B.: Monitoring flood and discharge variations in the large Siberian rivers from a multi-satellite technique, Surv. Geophys., 29, 297-317, doi:10.1007/s10712-008-9036-0, 2008.

Papa, F., Prigent, C., Aires, F., Jimenez, C., Rossow, W. B., and Matthews, E.: Interannual variability of surface water extent at the global scale, 1993-2004, J. Geophys. Res., 115, D12111, doi:10.1029/2009JD012674, 2010. 
Parton, W. J., Scurlock, J. M. O., Ojima, D. S., Gilmanov, T. G., Scholes, R. J., Schimel, D. S., Kirchner, T., Menaut, J. C., Seastedt, T., Moya, E. G., Kamnalrut, A., and Kinyamario, J. I.: Observations and modeling of biomass and soil organic-matter dynamics for the grassland biome worldwide, Global Biogeochem. Cy., 7, 785-809, 1993.

Pickett-Heaps, C. A., Jacob, D. J., Wecht, K. J., Kort, E. A., Wofsy, S. C., Diskin, G. S., Worthy, D. E. J., Kaplan, J. O., Bey, I., and Drevet, J.: Magnitude and seasonality of wetland methane emissions from the Hudson Bay Lowlands (Canada), Atmos. Chem. Phys., 11, 3773-3779, doi:10.5194/acp-11-37732011, 2011.

Pison, I., Ringeval, B., Bousquet, P., Prigent, C., and Papa, F.: Stable atmospheric methane in the 2000s: key-role of emissions from natural wetlands, Atmos. Chem. Phys. Discuss., 13, 9017-9049, doi:10.5194/acpd-13-9017-2013, 2013.

Potter, C. S.: An ecosystem simulation model for methane production and emission from wetlands, Global Biogeochem. Cy., 11, 495-506, 1997.

Prentice, I. C., Farquhar, G. D., Fasham, M. J. R., Goulden, M., Heimann, M., Jaramillo, V., Kheshgi, H., Quéré, C.-L., Scholes, R., and Wallace, D.: The Carbon Cycle and Atmospheric Carbon Dioxide, in: Climate Change 2001: The scientific basis, Contributions of Working Group I to the Third Assessment Report of the Intergovernmental Panel on Climate Change, edited by: Pitelka, L. F. and Rojas, A. R., Cambridge University Press, Cambridge, 183-237, 2001.

Prigent, C., Papa, F., Aires, F., Rossow, W. B., and Matthews, E.: Global inundation dynamics inferred from multiple satellite observations, 1993-2000, J. Geophys. Res., 112, 305-317, doi:10.1029/2006JD007847, 2007.

Prigent, C., Papa, F., Aires, F., Jimenez, C., Rossow, W. B., and Matthews, E.: Changes in land surface water dynamics since the 1990 s and relation to population pressure, Geophys. Res. Lett., 39, L08403, doi:10.1029/2012GL051276, 2012.

Qian, T. T., Dai, A., Trenberth, K. E., and Oleson, K. W.: Simulation of global land surface conditions from 1948 to 2004, part I: forcing data and evaluations, J. Hydrometeorol., 7, 953-975, 2006.

Ridgwell, A., Marshall, S. J., and Gregson, K.: Consumption of atmospheric methane by soils: a process-based model, Global Biogeochem. Cy., 13, 59-70, 1999.

Riley, W. J., Subin, Z. M., Lawrence, D. M., Swenson, S. C., Torn, M. S., Meng, L., Mahowald, N. M., and Hess, P.: Barriers to predicting changes in global terrestrial methane fluxes: analyses using CLM4Me, a methane biogeochemistry model integrated in CESM, Biogeosciences, 8, 1925-1953, doi:10.5194/bg-8-19252011, 2011.

Ringeval, B.: Interactions entre climat et émissions de méthane par les zones humides à l'échelle global, $\mathrm{Ph}$. D. thesis, Université Pierre \& Marie Curie, Paris, France, 2011.

Ringeval, B., de Noblet-Ducoudre, N., Ciais, P., Bousquet, P., Prigent, C., Papa, F., and Rossow, W. B.: An attempt to quantify the impact of changes in wetland extent on methane emissions on the seasonal and interannual time scales, Global Biogeochem. Cy., 24, 611-617, 2010.

Ringeval, B., Friedlingstein, P., Koven, C., Ciais, P., de NobletDucoudré, N., Decharme, B., and Cadule, P.: Climate- $\mathrm{CH}_{4}$ feedback from wetlands and its interaction with the climate-
$\mathrm{CO}_{2}$ feedback, Biogeosciences, 8, 2137-2157, doi:10.5194/bg8-2137-2011, 2011.

Ringeval, B., Decharme, B., Piao, S. L., Ciais, P., Papa, F., de Noblet-Ducoudré, N., Prigent, C., Friedlingstein, P., Gouttevin, I., Koven, C., and Ducharne, A.: Modelling sub-grid wetland in the ORCHIDEE global land surface model: evaluation against river discharges and remotely sensed data, Geosci. Model Dev., 5, 941-962, doi:10.5194/gmd-5-941-2012, 2012.

Ringeval, B., Hopcroft, P. O., Valdes, P. J., Ciais, P., Ramstein, G., Dolman, A. J., and Kageyama, M.: Response of methane emissions from wetlands to the Last Glacial Maximum and an idealized Dansgaard-Oeschger climate event: insights from two models of different complexity, Clim. Past, 9, 149-171, doi:10.5194/cp-9-149-2013, 2013.

Roulet, N. T., Moore, T. R., Bubier, J., and Lafleur, P.: Northern fens: methane flux and climate change, Tellus, 44B, 100-106, 1992.

Schroeder, R., Rawlins, M. A., McDonald, K. C., Podest, E., Zimmermann, R., and Kueppers, M.: Satellite microwave remote sensing of North Eurasian inundation dynamics: development of coarse-resolution products and comparison with high-resolution synthetic aperture radar data, Environ. Res. Lett., 5, 1441514428, 2010.

Segers, R. and Leffelaar, P. A.: Modeling methane fluxes in wetlands with gas-transporting plants 3, plot scale, J. Geophys. Res., 106, 3541-3558, 2001.

Sellers, P. J., Meeson, B. W., Closs, J., Corprew, F., Dazlich, D., Hall, F. G., Kerr, Y., Koster, R., Los, S., Mitchell, K., McManus, J., Myers, D., Sun, K.-J., and National Aeronautics and Space Administration and Goddard Space Flight Center, P. J. T.: International Satellite Land Surface Climatology Project - Initiative I data collection (ISLSCP I), available at: http://badc nerc.ac.uk/view/badc.nerc.ac.uk__ATOM_dataent_ISLSCP (last access: 1 September 2012), 1996.

Sheng, Y. W., Smith, L. C., MacDonald, G. M., Kremenetski, K. V., Frey, K. E., elichko, A. A., Lee, M., Beilman, D. W., and Dubinin, P.: A high-resolution GIS-based inventory of the west Siberian peat carbon pool, Global Biogeochem. Cy., 18, 1441514428, 2004.

Shindell, D. T., Walter, B. P., and Faluvegi, G.: Impacts of climate change on methane emissions from wetlands, Geophys. Res. Lett., 31, L21202, doi:10.1029/2004GL021009, 2004.

Singarayer, J. S., Valdes, P. J., Friedlingstein, P., Nelson, S., and Beerling, D. J.: Late Holocene methane rise caused by orbitally controlled increase in tropical sources, Nature, 470, 82-91, 2011.

Sitch, S., Smith, B., Prentice, I. C., Arneth, A., Bondeau, A., Cramer, W., Kaplan, J. O., Levis, S., Lucht, W., Sykes, M. T., Thonicke, K., and Venevsky, S.: Evaluation of ecosystem dynamics, plant geography and terrestrial carbon cycling in the LPJ dynamic global vegetation model, Glob. Change Biol., 9, 161-185, 2003.

Spahni, R., Wania, R., Neef, L., van Weele, M., Pison, I., Bousquet, P., Frankenberg, C., Foster, P. N., Joos, F., Prentice, I. C., and van Velthoven, P.: Constraining global methane emissions and uptake by ecosystems, Biogeosciences, 8, 1643-1665, doi:10.5194/bg-8-1643-2011, 2011.

Stillwell-Soller, L. M., Klinger, L. F., Pollard, D., and Thompson, S. L.: The Global Distribution of Freshwater Wetlands, Tech. Rep. NCAR/TN-416+STR, NCAR, available 
at: http://www.cisl.ucar.edu/ess/services/dbst/wetlands/ (last access: 11 September 2012), 1995.

Stocker, B. D., Strassmann, K., and Joos, F.: Sensitivity of Holocene atmospheric $\mathrm{CO}_{2}$ and the modern carbon budget to early human land use: analyses with a process-based model, Biogeosciences, 8, 69-88, doi:10.5194/bg-8-69-2011, 2011.

Strassmann, K. M., Joos, F., and Fischer, G.: Simulating effects of land use changes on carbon fluxes: past contributions to atmospheric $\mathrm{CO}_{2}$ increases and future commitments due to losses of terrestrial sink capacity, Tellus B, 60, 583-603, doi:10.1111/j.1600-0889.2008.00340.x, 2008.

Tarnocai, C., Swanson, D., Kimble, J., and Broll, J.: Northern Circumpolar Soil Carbon Database, Tech. Rep. Version 1, Research Branch, Agriculture and Agri-Food Canada, available at: http: //wms1.agr.gc.ca/NortherCircumpolar/northercircumpolar.zip (last access: 1 October 2012), 2007.

Tarnocai, C., Canadell, J. G., Schuur, E. A. G., Kuhry, P., Mazhitova, G., and Zimov, S.: Soil organic carbon pools in the northern circumpolar permafrost region, Global Biogeochem. Cy., 23, GB2023, doi:10.1029/2008GB003327, 2009.

Tian, H., Xu, X., Liu, M., Ren, W., Zhang, C., Chen, G., and Lu, C.: Spatial and temporal patterns of $\mathrm{CH}_{4}$ and $\mathrm{N}_{2} \mathrm{O}$ fluxes in terrestrial ecosystems of North America during 1979-2008: application of a global biogeochemistry model, Biogeosciences, 7, 2673-2694, doi:10.5194/bg-7-2673-2010, 2010.

Tian, H. Q., Melillo, J., Lu, C. Q., Kicklighter, D., Liu, M. L., Ren, W., Xu, X. F., Chen, G. S., Zhang, C., Pan, S. F., Liu, J. Y., and Running, S.: China's terrestrial carbon balance: contributions from multiple global change factors, Global Biogeochem. Cy., 25, 222-240, $2011 \mathrm{a}$.

Tian, H. Q., Xu, X. F., Lu, C. Q., Liu, M. L., Ren, W., Chen, G. S., Melillo, J., and Liu, J. Y.: Net exchanges of $\mathrm{CO}_{2}, \mathrm{CH}_{4}$, and $\mathrm{N}_{2} \mathrm{O}$ between China's terrestrial ecosystems and the atmosphere and their contributions to global climate warming, J. Geophys. Res., 116, G02011, doi:10.1029/2010JG001393, 2011 b.

Tian, H. Q., Lu, G., Chen, G. S., Tao, S., Pan, S. F., Del Grosso, S. J., Xu, X. F., Bruhwiler, L., Wofsy, S. C., Kort, E. A., and Prior, S. A.: Contemporary and projected biogenic fluxes of methane and nitrous oxide in terrestrial ecosystems of North America, Frontiers in Ecology and the Environment, 10, 528536, doi:10.1890/120057, 2012.

Valdes, P. J., Beerling, D. J., and Johnson, C. E.: The ice age methane budget, Geophys. Res. Lett., 32, 941-962, 2005.

van Bodegom, P., Goudriaan, J., and Leffelaar, P.: A mechanistic model on methane oxidation in a rice rhizosphere, Biogeochem., 55, 145-177, 2001a.

van Bodegom, P., Wassmann, R., and Metra-Corton, T.: A processbased model for methane emission predictions from flooded rice paddies, Global Biogeochem. Cy., 15, 247-263, $2001 \mathrm{~b}$.

Viovy, N. and Ciais, P.: CRUNCEP data set for 1901-2008, Tech. Rep. Version 4, Laboratoire des Sciences du Climat et de l'Environnement, available at: http://dods.extra.cea.fr/data/ p529viov/cruncep/, last access: 1 September 2011.

Walter, B. P. and Heimann, M.: A process-based, climate-sensitive model to derive methane emissions from natural wetlands: application to five wetland sites, sensitivity to model parameters, and climate, Global Biogeochem. Cy., 14, 745-765, 2000.

Walter, B. P., Heimann, M., Shannon, R. D., and White, J. R.: A process-based model to derive methane emissions from natural wetlands, Geophys. Res. Lett., 23, 3731-3734, 1996.

Walter, B. P., Heimann, M., and Matthews, E.: Modeling modern methane emissions from natural wetlands 1 , model description and results, J. Geophys. Res., 106, 34189-34206, 2001a.

Walter, B. P., Heimann, M., and Matthews, E.: Modeling modern methane emissions from natural wetlands 2 , interannual variations 1982-1993, J. Geophys. Res., 106, 34207-34219, 2001 b.

Wania, R., Ross, I., and Prentice, I. C.: Integrating peatlands and permafrost into a dynamic global vegetation model, I: evaluation and sensitivity of physical land surface processes, Global Biogeochem. Cy., 23, GB3014, doi:10.1029/2008GB003412, 2009a.

Wania, R., Ross, I., and Prentice, I. C.: Integrating peatlands and permafrost into a dynamic global vegetation model, II: evaluation and sensitivity of vegetation and carbon cycle processes, Global Biogeochem. Cy., 23, GB3015, doi:10.1029/2008GB003413, 2009b.

Wania, R., Ross, I., and Prentice, I. C.: Implementation and evaluation of a new methane model within a dynamic global vegetation model: LPJ-WHyMe v1.3.1, Geosci. Model Dev., 3, 565-584, doi:10.5194/gmd-3-565-2010, 2010.

Weaver, A. J., Eby, M., Wiebe, E. C., Bitz, C. M., Duffy, P. B., Ewen, T. L., Fanning, A. F., Holland, M. M., MacFadyen, A., Matthews, H. D., Meissner, K. J., Saenko, O., Schmittner, A., Wang, H. X., and Yoshimori, M.: The UVic Earth System Climate Model: model description, climatology, and applications to past, present and future climates, Atmos. Ocean, 39, 361-428, 2001.

Weber, S. L., Drury, A. J., Toonen, W. H. J., and van Weele, M.: Wetland methane emissions during the Last Glacial Maximum estimated from PMIP2 simulations: Climate, vegetation, and geographic controls, J. Geophys. Res., 115, D06111, doi:10.1029/2009JD012110, 2010.

Woodward, F. I., Smith, T. M., and Emanuel, W. R.: A global land primary productivity and phytogeography model, Global Biogeochem. Cy., 9, 471-490, 1995.

Xu, X. F., Tian, H. Q., Zhang, C., Liu, M. L., Ren, W., Chen, G. S., Lu, C. Q., and Bruhwiler, L.: Attribution of spatial and temporal variations in terrestrial methane flux over North America, Biogeosciences, 7, 3637-3655, doi:10.5194/bg-7-3637-2010, 2010.

Zhuang, Q., Melillo, J. M., Kicklighter, D. W., Prinn, R. G., McGuire, A. D., Steudler, P. A., Felzer, B. S., and Hu, S.: Methane fluxes between terrestrial ecosystems and the atmosphere at northern high latitudes during the past century: A retrospective analysis with a process-based biogeochemistry model, Global Biogeochem. Cy., 18, GB3010, doi:10.1029/2004GB002239, 2004

Zhuang, Q., Melillo, J. M., Sarofim, M. C., Kicklighter, D. W., McGuire, A. D., Felzer, B. S., Sokolov, A., Prinn, R. G., Steudler, P. A., and $\mathrm{Hu}, \mathrm{S} .: \mathrm{CO}_{2}$ and $\mathrm{CH}_{4}$ exchanges between land ecosystems and the atmosphere in northern high latitudes over the 21st century, Geophys. Res. Lett., 33, L17403, doi:10.1029/2006GL026972, 2006.

Zobler, L.: A world soil file for global climate modelling, Technical Memorandum 87802, 32, NASA, 1986.

Zürcher, S., Spahni, R., Joos, F., Steinacher, M., and Fischer, H.: Impact of an abrupt cooling event on interglacial methane emissions in northern peatlands, Biogeosciences, 10, 1963-1981, doi:10.5194/bg-10-1963-2013, 2013. 